\title{
Circular Economy in China: Translating Principles into Practice
}

\author{
Marco Pesce ${ }^{1}{ }^{(}$, Ilaria Tamai ${ }^{1}$, Deyan Guo ${ }^{1,2}$, Andrea Critto ${ }^{1, *(D)}$, Daniele Brombal ${ }^{1}(\mathbb{D}$, \\ Xiaohui Wang ${ }^{2}$, Hongguang Cheng ${ }^{3}$ and Antonio Marcomini ${ }^{1}$ \\ 1 Department of Environmental Sciences, Informatics and Statistics, University Ca' Foscari of Venice, \\ 30123 Venezia VE, Italy; marco.pesce@unive.it (M.P.); 856137@stud.unive.it (I.T.); \\ human@ehsacademy.org (D.G.); daniele.brombal@unive.it (D.B.); marcom@unive.it (A.M.) \\ 2 EHS Academy, Lingnan College, Sun Yat-Sen University, Guangzhou 510275, China; \\ wangxh@mail.sysu.edu.cn \\ 3 School of Environment, State Key Laboratory of Water Environment Simulation, Beijing Normal University, \\ Beijing 100875, China; chg@bnu.edu.cn \\ * Correspondence: critto@unive.it; Tel.: +39-041-234-8975
}

Received: 10 December 2019; Accepted: 18 January 2020; Published: 22 January 2020

check for updates

\begin{abstract}
The concept of circular economy (CE) has recently gained momentum in the political, scientific, and economic debate, especially in China and Europe. As a result, organizations and scholars have started to establish different sets of principles for its adoption. For this reason, it is important to identify and assess the differences and similarities among existing sets of CE principles, and how organizations and individuals understand and translate them into practice. In this paper, we firstly present a brief review and analysis of the coherence among six existing sets of principles. Our analysis finds that, despite the mixed degree of coherence, all sets describe the necessity to implement CE principles at all levels of a company. We then present the results of an in-depth qualitative survey that investigates how 19 key informants representing small, medium, and multinational companies based in China understand and carry out the CE principles laid out by the BSI standard BS 8001:2017; how these principles can transform the culture and processes of these companies; and what are the opportunities and threats that such transformation can bring. Results describe a good awareness and knowledge of the CE principles and an optimistic outlook concerning their adoption. At the same time, numerous barriers and threats that the implementation of these principles might entail are presented. Overall, respondents confirm the complexity of implementing the principles of the CE in an integrated and consistent way in the management and strategies of Chinese companies and highlight the challenges that might arise during their implementation.
\end{abstract}

Keywords: circular economy; principles; Small \& Medium Enterprises (SMEs); China; circular innovation; drivers and barriers

\section{Introduction}

The current state of the planet calls for a fast transition towards a circular economic model built on making the best use of the planet's resources and eliminating the concept of waste. Despite its origins dating back to the 1970s, it is only in the last decade that the concept of circular economy (CE) has gained international momentum among both scholars and practitioners [1,2]. The sparking reason for this consists of the realization of the adverse effects that the currently dominant linear production model based on taking, making, and disposing of resources and goods is having on the environment and human health [3]. Geissdoerfer et al. [4] found that the majority of peer-reviewed articles on CE were published only in recent years, increasing from 30 articles a year in 2014 to more than 100 articles a year 
in 2016. Another evidence is the number of reports and white papers published by major consulting firms such as Accenture; Deloitte, Ernst \& Young; and McKinsey [5-8]. Finally, international objectives for the achievement of a global CE can be found in the United Nations' Sustainable Development Goals (SDGs). Specifically, Global Goal 12 aims to ensure sustainable consumption and production patterns and includes targets that aim at achieving more efficient use of resources (target 12.2) and reducing waste generation through prevention, reduction, recycling, and reuse (target 12.5) [9].

Today, a commonly agreed definition of CE is still missing, and the range of given definitions is recognizably broad $[10,11]$. Currently, the most widely accepted definition is the one provided by the Ellen MacArthur Foundation [12], which describes a CE as "one that is restorative and regenerative by design and aims to keep products, components, and materials at their highest utility and value at all times, distinguishing between technical and biological cycles." In other words, a CE is an alternative form of economic model that aims at decoupling global economic development from finite resource consumption. Differences in the way the $\mathrm{CE}$ is defined and implemented are observable also at the governmental level. European Union (EU) and China, both at the forefront of research and practical implementation of the CE [13], have matured different definitions.

The European Commission (EC) defines CE as an economic model in which "the value of products and materials is maintained for as long as possible. Waste and resource use are minimized, and when a product reaches the end of its life, it is used again to create further value" [14]. The EC's view on the $\mathrm{CE}$ focuses on the value of products and resources and aims at promoting the minimization of their use and waste. One of the EC's first steps towards the implementation of a CE at the communitarian level was the 2008 Regulation on Waste [15] (further revised in 2018 [16], where it clearly states how waste management is a fundamental aspect for the implementation of a CE in the EU) in which the $4 R$ framework (reduce, reuse, recycle, recover) is presented as the core of the policy [11,15]. Finally, in 2015, the European Commission adopted a 54-point Circular Economy Action Plan [17]. The plan was put into action between 2015 and 2019, covering the entire life cycle of materials and products-from production and consumption to waste management and the market for secondary raw materials $[18,19]$.

The notion of CE prevalent in the Chinese context can be described as "a generic term for the reducing, reusing and recycling activities conducted in the process of production, circulation, and consumption", reflecting the bond with the 3R framework (reduce, reuse, recycle) [20]. China considers CE as a national policy. In China, policies toward a CE have started with the Hu-Wen administration. At the legislative level, the first milestone was the adoption, in 2008, of the Circular Economy Promotion Law of the People's Republic of China [21], which was subsequently amended in 2018 [22]. Macro socio-economic policies have provided an important platform for the introduction and enhancement of CE in China. In the Eleventh Five-Year Plan (2006-2010), Part Six, Chapter Twenty-Two is dedicated to the CE [23]. A further reference to CE can be found in the $43^{\text {rd }}$ Chapter of China's Thirteenth Five-Year Plan (2016-2020) [24], which validates the importance of CE both as a national policy and as a fundamental pillar of the Chinese economy [25]. This sustained effort of the Chinese government has brought to a comprehensive set of policies that Zhu and colleagues [26] have classified in four general types: generation of more valuable resource flows, production efficiency and environmental performance, prevention of waste disposal and associated pollution, and sustainable consumption and life cycle considerations. Recent market instability created by international trade tensions could become one of the drivers pushing Chinese companies towards greener business solutions to maintain their advantages in the international trade context [27]. This possibility is in agreement with the view of a "Green Development" and "Beautiful China" promoted by the current Chinese leadership [28,29], which can be summarized in the motto "Green water and blue mountains are equal to mountains made of gold and silver," [30], conveying the idea that a clean environment brings profit to the nation. In this perspective, China has already made some necessary steps, realizing that a market-based approach could provide a significant contribution in encouraging Chinese businesses to pursue a more sustainable path, instead of issuing targeted incentives given only to national key eco-industrial Areas, which did not always provide the expected outcomes [31]. 
Results are already observable; in 2019, one Chinese enterprise, Tianjin Citymine Ltd. (Tianjin, China), and the non-profit organization Shandong Association for Circular Economy have reached the final stages of the Circulars Awards, an initiative promoted by the World Economic Forum (WEF) and the Forum of Young Global Leaders [32].

\subsection{Rationale, Goals, and Structure of the Paper}

While plenty of evidence is available today about top-down and international initiatives taken to establish CE in China, much less is known about how the notion of CE is translated into practice by organizations and individuals. In fact, CE operates at three levels of scale: macro (globally [33,34], within countries [26,35,36], regions or cities [37-39]); meso (eco-industrial parks and supply-chains [40-42]); and micro (single organizations [43], including its products and services [11,44]). The study at the micro-level is fundamental because the CE is described as one of the most prospective approaches that companies can adopt to address current and future sustainability challenges [45-47]. Moreover, the transition to a CE can bring financial gains and a series of additional values that Koppius and colleagues [48] classify in four categories: sourcing value (direct cost reduction and saving), environmental value (improved ecological footprint), customer value (increased customer loyalty and satisfaction) and informational value (valuable data on production and supply problems). However, to achieve such benefits and avoid negative side-effects or unseen consequences [49], organizations must overcome numerous barriers and challenges, such as changing the key building blocks of their business strategies, transforming the way they manage their operations [50], and redesigning their products and services [51]. Despite the urgent necessity to address these challenges, the academic debate on CE within the business and sustainability literature is still very limited $[11,46]$ and mainly focused on the analysis and design of circular business models (CMBs) [52-55] and development of specific key performance indicators (KPIs) for the CE [56-59]. As of today, there is a lack of studies on the awareness of organizations of the principles of the CE and on how to turn them into practice [50,60]. Being comfortable around the principles of the CE allows companies to understand their role in the global $\mathrm{CE}$, identify opportunities and threats, and improve or completely re-design their value proposition, thus moving towards more sustainable operations that have the potential to create, both directly and indirectly, significant added value [61].

This explorative study seeks to enrich the existing theories of the CE at the level of organizations, providing new insights on how small and medium companies (SMEs) and multinational companies (MNCs) approach and implement the principles of the CE. The study mainly focuses on China, which has introduced the circular economy as a new form of development to leapfrog into a more sustainable economic structure. However, it is expected to be useful also for researchers and practitioners from other countries. It also provides numerous practical information for practitioners concerned with managing sustainability aspects in organizations. Our work is informed by the awareness that, to develop an effective CE strategy, companies must be capable of managing, implementing, and measuring performance against the principles of the CE. In this regard, the paper provides essential insights on how the principles of the CE can affect the companies' cultures, behaviour, decision-making and operations, and what are the opportunities and threats that such transformation can bring.

We have investigated these aspects employing an in-depth qualitative survey, engaging a sample of 19 key informants, all Chinese practitioners employed in a wide range of industry fields. The paper is organized into six sections: Section 1.2 provides definitions for core principles informing CE, based on a review of international standards and scientific literature. Selected definitions obtained in the review have been employed to define the survey protocol, which is explained in detail in Section 2, along with methods adopted in our study. Section 3 introduces results, highlighting the current understanding and implementation of CE in China, as well as perceived strengths, weaknesses, opportunities, and threats. The conclusive Section 4 summarizes the main findings, highlights relevant implications for practice and research, and suggests future research directions. 


\subsection{A Short Review of Circular Economy Principles}

"Principles" can be defined as the "fundamental basis for decision making or behaviour" [62]. With specific reference to the adoption of $\mathrm{CE}$, principles can provide a path for businesses to reach their CE goals, and therefore they should be considered as an essential basis for the decision-making process [61]. Hence, principles convey the idea of how the companies implement CE and operate in this sense [10].

Overall, CE draws from principles of multiple schools of thought, including cleaner production [63], industrial ecology [64] and symbiosis [65], performance economy [66], biomimicry [67], cradle to cradle [68], blue economy [69], regenerative design [70] and natural capitalism [71]. This heterogeneity implies that a commonly agreed set of principles has not yet been defined. As a result, recent years have seen the birth of different proposed sets of principles. The consequence of this proliferation threatens to become overwhelming and confusing for the practitioner, who might encounter two potential problems, as described in Floridi and Cowls [72] in the field of ethical artificial intelligence. Either the various sets of principles for $\mathrm{CE}$ are similar, thus generating unnecessary repetition and redundancy, or they differ significantly, with the consequence of creating confusion and ambiguity among professionals. In the latter case, the proliferation of diverse sets of principles can create a real "market for principles" [73], where organizations and stakeholders are encouraged to choose for those principles that most justify and do not hinder their current behaviours. Consequently, this would end up expanding the already pervasive practice of greenwashing among organizations.

In this section, we identify and characterize six complementary sets of principles for the CE, and we qualitatively assess whether these principles are convergent (if present in four or more sets) or divergent (if present in three or fewer sets), among the six sets. Altogether, the six sets yield 31 principles, with Circle Economy [74] and Suárez-Eiroa and colleagues [10] offering the largest number of principles (seven), and Ellen MacArthur [75] proposing the smallest number (three). The six sets are presented and described in Table 1.

Overall, the qualitative assessment obtained by the careful reading of the principles portrays a mixed degree of coherence between sets. Six principles are convergent, even though the different naming of the principles might hide the similarities at first glance: systems thinking, innovation, value optimization, resource recovery, circular design of processes, products and services, and waste as a resource. In contrast, six principles turned out to be divergent: stewardship, resilience, collaboration, transparency, education, and minimization of externalities.

Despite the diversity among the six sets, all of them highlight the necessity to implement the principles of the $\mathrm{CE}$ in numerous facets of the company. Therefore, understanding how the $\mathrm{CE}$ principles operate at the company level and how they can affect the creation of value, management, decision-making processes, leadership, and culture of a business is of crucial importance. 
Table 1. Set of Circular Economy (CE) principles from different sources.

\begin{tabular}{|c|c|c|}
\hline Source & Principles & Description \\
\hline \multirow{6}{*}{$\begin{array}{l}\text { BS 8001:2017, The British } \\
\text { Standards Institution [61] }\end{array}$} & Systems thinking & $\begin{array}{l}\text { Adoption of a holistic approach to understanding the interaction within the broader } \\
\text { systems. }\end{array}$ \\
\hline & Innovation & $\begin{array}{l}\text { Innovation to create value by better managing resources through the design of } \\
\text { processes, products/services, and business models. }\end{array}$ \\
\hline & Stewardship & $\begin{array}{l}\text { Management of direct and indirect impacts of decisions and activities within the } \\
\text { broader system of a company. }\end{array}$ \\
\hline & Collaboration & $\begin{array}{l}\text { Internal and external collaboration through formal and informal arrangements to create } \\
\text { mutual value. }\end{array}$ \\
\hline & Value optimization & Products, components, and materials are always kept at their highest value and utility. \\
\hline & Transparency & $\begin{array}{l}\text { Willingness to communicate circular and sustainability practices in a transparent, } \\
\text { accurate, timely, honest, and complete manner. }\end{array}$ \\
\hline \multirow{7}{*}{ Circle Economy [74] } & Prioritize regenerative resources & Renewable, reusable, non-toxic resources are efficiently utilized as materials and energy. \\
\hline & Preserve and extend what is already made & $\begin{array}{l}\text { Products are maintained, repaired, and upgraded to maximize lifetime and give them a } \\
\text { second life when applicable. }\end{array}$ \\
\hline & Use waste as a resource & $\begin{array}{l}\text { Waste streams are used as a source of secondary resources and recovered for reuse and } \\
\text { recycling. }\end{array}$ \\
\hline & Rethink the business model & $\begin{array}{l}\text { Business models that blur the distinction between products and services, creating } \\
\text { higher value and aligning incentives. }\end{array}$ \\
\hline & Design for the future & $\begin{array}{l}\text { Think in systems during the design process, use the right materials, design for an } \\
\text { appropriate lifetime and extended future use. }\end{array}$ \\
\hline & Incorporate digital technology & $\begin{array}{l}\text { Tracking and optimization of resource use stronger connections between supply chain } \\
\text { actors through technology. }\end{array}$ \\
\hline & Collaborate to create joint value & Internal and external collaborations to increase transparency and create joint value. \\
\hline \multirow{3}{*}{$\begin{array}{l}\text { Ellen Macarthur } \\
\text { Foundation [76] }\end{array}$} & Design out waste and pollution & $\begin{array}{l}\text { A new mindset that sees waste as a design flaw and uses new materials and } \\
\text { technologies. }\end{array}$ \\
\hline & Keep products and materials in use & $\begin{array}{l}\text { Products and materials are kept in the economy through reuse, repair, and } \\
\text { remanufacture. Materials are collected to be reused. }\end{array}$ \\
\hline & Regenerate natural systems & Valuable nutrients are returned to the environment to regenerate natural ecosystems. \\
\hline
\end{tabular}


Table 1. Cont

\begin{tabular}{|c|c|c|}
\hline Source & Principles & Description \\
\hline \multirow{7}{*}{ Suárez-Eiroa et al. [15] } & $\begin{array}{l}\text { Adjusting inputs to the system to regeneration } \\
\text { rates }\end{array}$ & $\begin{array}{l}\text { Input of non-renewable resources is minimized/eliminated, and the extraction rate of } \\
\text { renewable resources is adjusted to suitable values. }\end{array}$ \\
\hline & $\begin{array}{l}\text { Adjusting outputs from the system to } \\
\text { absorption rates }\end{array}$ & $\begin{array}{l}\text { Output of technological waste is minimized/eliminated, and the emission rate of } \\
\text { biological waste is adjusted to suitable values. }\end{array}$ \\
\hline & Closing the system & Connection of the waste management stage to the resource acquisition stage. \\
\hline & Maintaining resource value within the system & $\begin{array}{l}\text { Improvement of products' durability and recirculation of resources through different } \\
\text { stages of products' life cycles. }\end{array}$ \\
\hline & Reducing the system's size & $\begin{array}{l}\text { The total amount of resources that circulate within the system is reduced; Overall } \\
\text { improvement of the global production-consumption process. }\end{array}$ \\
\hline & Designing for $\mathrm{CE}$ & Shift from a linear production-consumption model into a circular one. \\
\hline & Educating for $\mathrm{CE}$ & $\begin{array}{l}\text { Change in education, values, and behaviour of producers and consumers: new } \\
\text { consumption culture and paradigm. }\end{array}$ \\
\hline \multirow{4}{*}{ Weetman C. [77] } & Waste $=$ food & $\begin{array}{l}\text { In living systems, there is no such thing as "waste"-one species" waste becomes food } \\
\text { for another species. }\end{array}$ \\
\hline & Build resilience through diversity & Use of diversity to strengthen the overall health of the system, creating resilience. \\
\hline & Use renewable energy & Use renewable energy sources in all CE processes. \\
\hline & Think in systems & $\begin{array}{l}\text { Connections between ideas, people, and places to create opportunities for people, } \\
\text { planet, and profit. }\end{array}$ \\
\hline \multirow{4}{*}{ Tonelli M., Cristoni N. [78] } & Green-tech and responsible use of resources & $\begin{array}{l}\text { Switch to renewable energy sources. Virgin raw material extraction is reduced to a } \\
\text { minimum. }\end{array}$ \\
\hline & Maximize utilization rate & Assets are exploited fully by maximizing their utilization rates. \\
\hline & Product and materials at the highest utility & Development of capabilities to set up circular flows of materials and products. \\
\hline & Minimize and phase out negative externalities & $\begin{array}{l}\text { Gradual achievement of zero negative environmental externalities (water/air pollution, } \\
\text { soil degradation). }\end{array}$ \\
\hline
\end{tabular}




\section{Methods}

\subsection{Survey Design}

The first step consisted of the selection of a set of CE principles among those illustrated in Table 1. The goal of the study dictated the rationale behind the choice, which had to fulfil the following criteria: (a) being developed by an international institution with the capability to promote and disseminate the principles in order to make them easily accessible for interested actors; (b) being developed for implementation at the micro level of companies; (c) operate at the leadership and managerial level within companies and organizations. According to these criteria, the six principles developed by the BSI in its BS 8001:2017 standard were the most suitable for the study. The BS 8001:2017 is the world's first CE standard. It was developed to "help organizations and individuals consider and implement more circular and sustainable practices within their businesses, whether through improved ways of working, providing more circular products and services or redesigning their entire business model and value proposition" [61]. The standard adopts a principle-based approach, and organizations are free to determine their level of alignment to its principles.

The survey was designed having both Likert scale survey questions and Strength, Weakness, Opportunity, and Threat Analyses (SWOT). Companies were asked to self-assess their implementation of CE principles through the completion, for each of the six principles, of four Likert scale questions and one SWOT analysis in an anonymous way. Additionally, respondents could add an optional comment for each principle. As a result, the questionnaire resulted in having 24 Likert scale questions, six SWOT analyses, and six optional comments. Figure 1 illustrates the survey framework relevant to the self-assessment of CE implementation (24 Likert-scale questions).

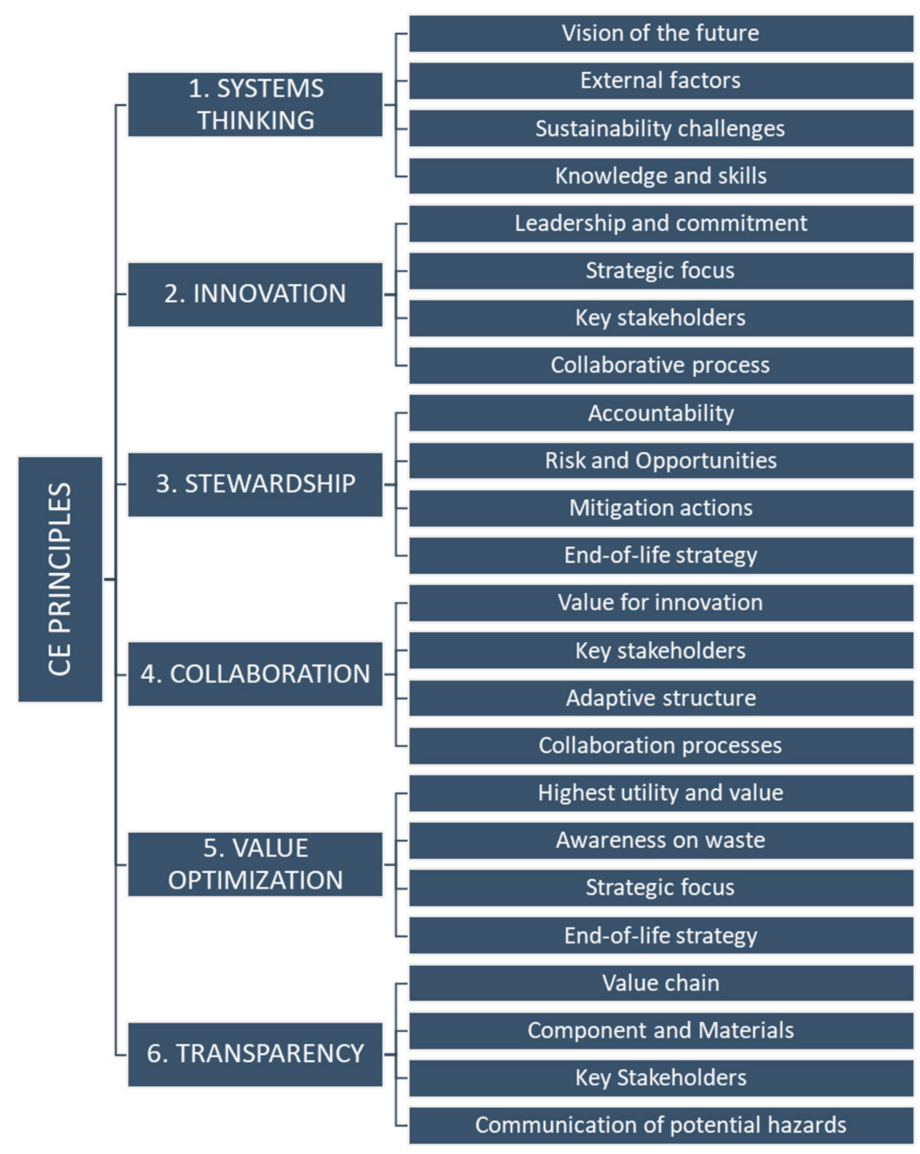

Figure 1. Criteria for self-assessment of CE implementation employed in the survey. Adjusted from BS 8001:2017. 
The Likert scale questions were developed using the guiding questions contained in the BS 8001:2017, Annex A, as a starting point. Questions were selected and adjusted based on (a) their relevance to dimensions being investigated (CE principle adoption process, resources to be mobilized, changes in strategies, required knowledge, need for collaborations), and (b) logical consistency with the metric employed (Likert scale). They ranged from "strongly disagree" to "strongly agree". The answer "neutral" indicates that the respondent does not have the competence to answer the question or that there are some aspects that prevent the question from being answered (nature of the company and its products or services, and the inapplicability of the principle to it). The questions aimed to evaluate the participants' attitudes (considered as "dispositions towards overt action" [79]) towards the six principles of the BS 8001:2017 and provide the respondents with an auto-evaluation method based on which they could understand their maturity and degree of implementation of CE principles. Given the low number of respondents, it was decided to analyse the results only from a qualitative perspective, without statistical tests.

The SWOT analysis was performed for each principle in order to understand how the companies perceive the CE principles in terms of Strengths and Weaknesses (internal factors) and Opportunities and Threats (external factors). The SWOT matrix is often employed in strategic planning to generate an overview of these features concerning a given project or topic [80,81]. SWOT analysis tables have been already used in several studies regarding the implementation of sustainability practices in companies, different industries, and territories, such as the application of ISO 14001 [82] and ISO 14006 [83] in enterprises, the development of the green energy industry [84], and the establishment of industrial symbiosis in a given area [85].

In this case, Strengths (S) represent those positive features of each principle, which can bring strength to the company's management and performance. Weaknesses (W) include all the negative aspects that could work against the development of functioning management practices and performance. Opportunities $(\mathrm{O})$ are those useful external factors that the implementation of the principles can bring to the company, while Threats $(\mathrm{T})$ embody those harmful external elements coming along with the adoption of the principle taken into consideration.

The SWOT analysis method was chosen because it suited nicely the qualitative approach of the survey, as well as its in-depth nature. Furthermore, given the logistical constraints of respondents, most of whom had to take part in the study in a remote fashion, SWOT provided a cost-effective option to collect several meaningful opinions. Moreover, SWOT has proved to be an inclusive framework: it is accessible and easily understandable. Indeed, participants can join and contribute to the research without the need for lengthy training or substantial technical support [82].

The survey was fielded online in English and in a fully anonymous way through the Web-based platform WJX (https://www.wjx.cn). Invitations with the link to the questionnaire and reminders were sent by e-mail to the 19 participants. In order to lay a common cognitive ground across participants, the questionnaire included a baseline definition of each of the six principles touched upon by our survey, as exemplified in Table 2 below, relevant to Principle 1: Systems Thinking. Participants had one month to complete the questionnaire, from 1 June to 30 June 2019. At the end of the submission period, data were downloaded in a spreadsheet format and analysed in an aggregate and anonymous form for each principle. The complete survey is provided as supplementary materials in Annex I. 
Table 2. Survey format, Principle 1: Systems Thinking.

PRINCIPLE 1: SYSTEMS THINKING

Systems Thinking is about understanding the complex, nonlinear, and interconnected nature of a system in which a company operates. Systems can be living (natural systems) and non-living and include markets and supply chains. Thinking about relationships within a system is crucial to understanding how a company creates value and how it might be able to intervene in the "system" to influence the sustainable management of resources in its portfolio of products and services.

\begin{tabular}{|c|c|c|}
\hline QUESTIONS & SWOT & LLYSIS \\
\hline $\begin{array}{l}\text { The following four topics require you to choose one of the } \\
\text { options that best suits you and your company. } 1 \text { Strongly } \\
\text { disagree; } 2 \text { Disagree; } 3 \text { Neutral; } 4 \text { Agree; } 5 \text { Strongly Agree. If } \\
\text { you have any additional comments, please fill the } \\
\text { corresponding blank below. }\end{array}$ & Strengths & Weaknesses \\
\hline $\begin{array}{l}\text { 1.1. My company has determined a vision of the future for a } \\
\text { more circular and sustainable mode of operation. }\end{array}$ & \multirow{2}{*}{ Opportunities } & \multirow{2}{*}{ Threats } \\
\hline $\begin{array}{l}\text { 1.2. External factors always play a significant role in the } \\
\text { decision-making process within my organization. }\end{array}$ & & \\
\hline $\begin{array}{l}\text { 1.3. Systemic thinking would be a better approach in gaining } \\
\text { insights into present and future complex sustainability } \\
\text { challenges of my company (e.g., climate change, resource and } \\
\text { waste management, energy and water use, impacts on the } \\
\text { local community, knowing when to embrace change, and } \\
\text { future customer trends). } \\
\text { 1.4. My company has the knowledge and skills to understand } \\
\text { the processes and outcomes of systems thinking. }\end{array}$ & & \\
\hline
\end{tabular}

\subsection{Profile of Respondents}

The survey was administered to a sample of 19 companies located in China. Companies were selected through convenience sampling, stratified based on the size of the company (10 SMEs and 9 MNCs). Respondents were already engaged in sustainability related collaborative workshops (in order not to jeopardize the anonymity of survey respondents, we deem it appropriate not to disclose the full information of said workshops) coordinated by the authors of this paper. Figure 2a shows that most of the respondents (13) are in the Guangdong province, two in the Shanghai Municipality, and the remaining four are equally distributed among the Zhejiang, Jiangsu, Anhui, and Shaanxi provinces.

Figure $2 \mathrm{~b}$ shows that the eight respondents have an EHS (environment, health, and safety) position and one a QEHS (quality, environment, health, and safety) position. Three respondents are sustainability professionals, and one is a CSR (corporate social responsibility) consultant. The remaining six participants do not have direct involvement in sustainable matters inside their companies: four hold generic managerial positions, one is a senior auditor, and one is a customer service employee.

Concerning the participants' industries, Figure 2c illustrates the various participants' sectorial affiliations. Five participants are part of the auditing sector, three work in the engineering field, and three in the electronic industry. Two respondents each represent the textile and footwear sectors. One respondent comes from the apparel and accessory industry, and one works in the e-commerce industry. Finally, the health, beauty, and house-care industry and aerospace and defence industry have one respondent each. 
(b)

(a)

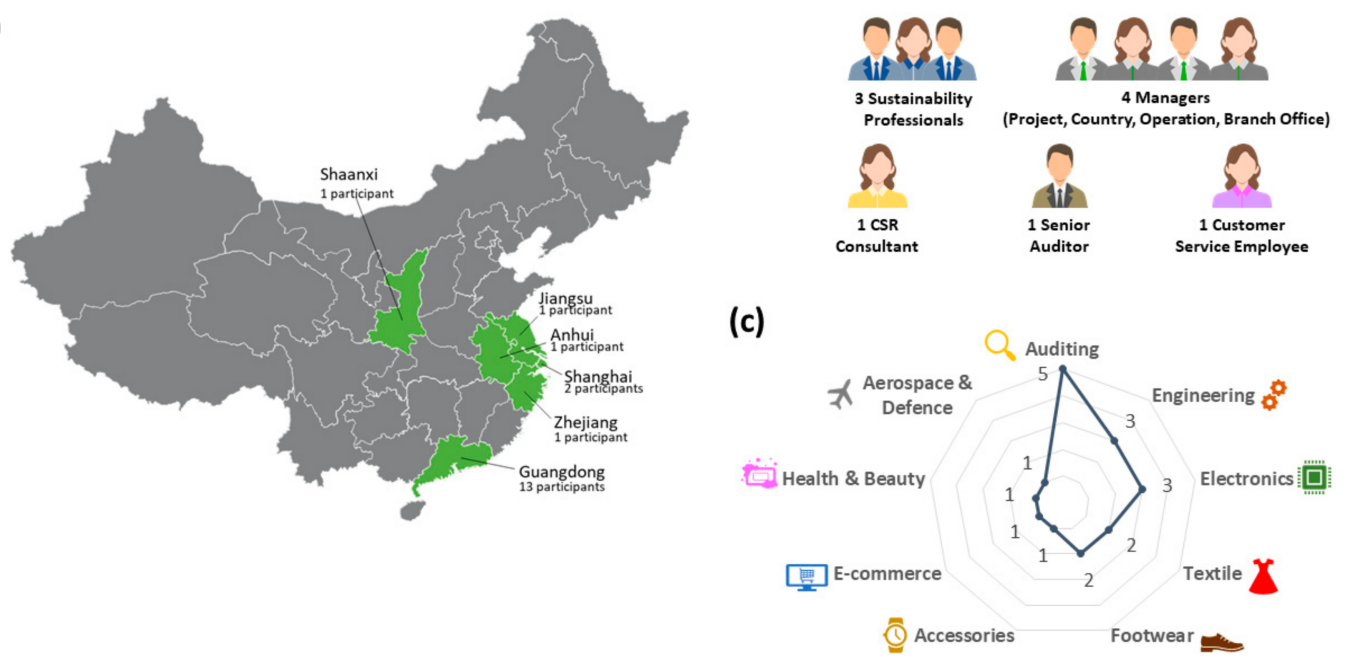

Figure 2. The graph indicates the geographical location (a), role in the company (b), and industry (c) of the 19 survey respondents. The sum of the participants equals 19.

\section{Results and Discussion}

This section is divided into two parts. The first part presents and discusses the results of the self-assessment survey about the attitudes of respondents toward the implementation of CE principles in their company. The second part presents and examines the SWOT surveys (Tables 3-8) to understand how the respondents perceive the CE principles in terms of Strengths and Weaknesses (internal factors) and Opportunities and Threats (external factors). The SWOT tables also indicate how many participants have identified each element (the absence of the number indicates that only one participant has identified that element).

Table 3. SWOT table presenting the respondents' comments on the systems thinking principle.

\begin{tabular}{|c|c|}
\hline \multicolumn{2}{|c|}{ Systems Thinking } \\
\hline Strengths: & Weaknesses: \\
\hline $\begin{array}{l}\text { - } \quad \text { Serves as guidance, principle, target and strategy } \\
\text { for implementing CE into organizations (6) } \\
\text { - } \quad \text { Systems thinking is easier to implement for } \\
\text { small size organizations (2) } \\
\text { - Triggers the involvement of experts and } \\
\text { experienced people (2) }\end{array}$ & $\begin{array}{l}\text { - Needs support (e.g., money, human resources, } \\
\text { training and attention from management team) (6) } \\
\text { Difficult to implement without a management } \\
\text { system in place (5) } \\
\text { - Can be easily affected by the lack of } \\
\text { understanding from employees (4) } \\
\text { - Can be easily affected by the limited engagement } \\
\text { with upstream and downstream stakeholders (3) } \\
\text { Lack of methods to implement systems thinking } \\
\text { in a profitable way (2) } \\
\text { If the organization has a general degree of } \\
\text { uncertainty about its activities and decision to } \\
\text { interact with wider system, it will be difficult to } \\
\text { implement systems thinking (2) } \\
\text { There is the need of communication between the } \\
\text { parties of the value chain }\end{array}$ \\
\hline
\end{tabular}


Table 3. Cont.

\begin{tabular}{ll}
\hline \multicolumn{1}{c}{ Systems Thinking } \\
\hline \multicolumn{1}{c}{ Opportunities: } \\
\hline $\begin{array}{l}\text { Can strengthen relationships with stakeholders } \\
\text { (e.g., public, government, customer and other } \\
\text { market actors) in coping with CE and } \\
\text { sustainability issues (8) } \\
\text { Can improved internal performance in term of } \\
\text { leadership, teamwork, work efficiency (5) } \\
\text { Can lead the management team to support and } \\
\text { improve management processes (4) } \\
\text { Can bring economic benefits and business } \\
\text { opportunities (e.g., companies get more orders } \\
\text { by adopting systems thinking) (4) } \\
\begin{array}{l}\text { Can stimulate organization in the search for } \\
\text { technological innovation and implementation of } \\
\text { new tools to enhance competitiveness (3) }\end{array}\end{array}$ \\
\hline
\end{tabular}

Table 4. SWOT table presenting the respondents' comments on the innovation principle.

\begin{tabular}{lll}
\hline & Innovation & Weaknesses: \\
\hline Strengths: & \\
\hline
\end{tabular}

- Innovation requires the companies to have the capacity, methods and mechanism to innovate (e.g., experts, budget) (6)

- Commitment to innovation is a strategy often supported by the top management (8)

- Innovation can help companies finding new opportunities by studying both internal and external factors (4)

- Maintain the competitiveness in the market while other companies do not innovate (2)
- The management has to be highly motivated, otherwise innovation cannot take place properly (2)

- $\quad$ There is a gap between theory and real application (2)

- The companies are driven by customers' requirement, which are not necessarily innovative

- The innovation process is usually very long. Time is required

- Supply chain management needs to be innovative as well, especially in the context of CE

- Innovation mostly focuses on quality of product and service. Environmental and social aspects are not the main driver

\section{Opportunities:} Threats:

- Innovation inspires new ideas and promotes the transformation of consumption and production to a more cyclical and sustainable business model (5)

- New tools and technology may be introduced, and R\&D may be upgraded (5)

- Innovation could improve the design of the product (3)

- The organization will be able to fulfil different demands from customers by offering innovative products (3)

- Improves profitability and brings economic benefits (3)

- Engaging in innovation increases the attractiveness of the organization, in particular for young talents and investors (2)

- $\quad$ Engages upstream and downstream to reduce waste (2)

- Encourages partnership and cooperation within same or different industries (2)

- The employees could gain the recognition from the companies for their innovative ideas

- Innovation could test the feasibility of CE

- Patent innovation

- Innovation might not bring enough economic benefits (9)

Innovative ideas could be easily copied by other competitors (2)

- Competition for innovation among players might be lost

- Innovation might not bring the desired change and damage the business

- Innovation might not be able to keep the pace of a fast-changing market

- Legal concerns from immature innovation 
Table 5. SWOT table presenting the respondents' comments on the stewardship principle.

\begin{tabular}{ccc}
\hline & Stewardship & \\
\hline Strengths: & Weaknesses: \\
\hline
\end{tabular}

- Reinforces leadership and motivates the implementation of CE (11)

- Can be shared or owned by organizations, individuals and communities (2)

- Can be implemented by all types of companies (size, industry, legal entity)

- Can help companies to deal with the uncertainty of the system in which it operates

- Requires employees to take the lead
- Requires awareness and resources (e.g., tools, trained people, systems) (8)

- Not effective if an organization has limitations on its operations (3)

- It takes time for a new or small organization to manage stewardship across its value chain (3)

- $\quad$ Lack of guided processes for improving stewardship (2)

- Stewardship requires effective communication between the organizations across the value chain (2)

- Highly dependent on top management's decision-making

- Stewardship is not always valued by costumers, especially in periods of economic recession, when they focus on cost/quality ratio

\section{Opportunities:}

\section{Threats:}

- Major customers' demand for CSR audit or CE drives the organization to manage its impact on every activity (4)

- The organization will be able to attract more customers and increase financial benefits by being accountable for its $\mathrm{CE}$ and sustainability practices (3)

- Possibilities to learn from universities, professionals and institutions committed to $\mathrm{CE}$ and sustainability issues (2)

- Social participation increases, brand integration, and industry tools are introduced (2)

- Can facilitate initiatives and joint effort with NGOs, local/national governments, customers and other relevant stakeholders (2)
- $\quad$ Requires consistency through time which can be difficult to perform in an environment with high staff turnover

- Can lead to an inefficient implementation in a complex organizational structure

- It is difficult to manage the use of products at end-of-life if the customers lack education on how to use and dispose them

- Fear of being misled by CE

- Increases labour cost

Table 6. SWOT table presenting the respondents' comments on the collaboration principle.

\begin{tabular}{|c|c|}
\hline \multicolumn{2}{|c|}{ Collaboration } \\
\hline Strengths: & Weaknesses: \\
\hline $\begin{array}{l}\text { - Facilitates the interaction with internal and } \\
\text { external stakeholders (4) } \\
\text { - Reduces the risk for an organization to operate } \\
\text { in a wrong way }\end{array}$ & $\begin{array}{l}\text { - } \quad \text { Lack of teamwork (5) } \\
\text { - } \quad \text { establish a useful collaboration (3) } \\
\text { Requires resources (time, money and } \\
\text { - } \quad \text { An organization's structure should be flexible in } \\
\text { order to establish fruitful collaborations (3) } \\
\text { - Requires the coordination of the } \\
\text { top-management (2) } \\
\text { - The collaboration is not clear } \\
\text { - The nature of the product/service can limit the } \\
\text { possibilities for collaboration } \\
\text { Insufficient links between departments may } \\
\text { hinder the possibility of a good collaboration } \\
\text { Different level of knowledge of CE and } \\
\text { sustainable development may hinder the pursue } \\
\text { of a successful collaboration }\end{array}$ \\
\hline
\end{tabular}


Table 6. Cont.

\begin{tabular}{lll}
\hline & Collaboration & \\
\hline Opportunities: & Threats: \\
\hline
\end{tabular}

- $\quad$ Can trigger improvements in many fields (financial situation, efficiency, knowledge, specialization) (3)

- Establishment of collaborations with important partners (2)

- Internal cooperation between employees in order to respect clients and suppliers CSR standards helps to improve the organization's performance (2)

- Facilitates the creation of a peaceful environment between companies at the local level

- A way for the organization to gain a competitive advantage

- Can trigger the change of Business Model to fit the CE

- Helps to gain support and resources

- Can drive the creation of value

- Can improve the organizational structure by making it more flexible

- Facilitates the compliance with national, local, international directives

- Internal coordination and cooperation can provide a better knowledge and understanding of the organization's sustainability aspects

- Collaboration with academies and pioneers can contribute to acquire expertise, leadership and stewardship necessary to improve sustainability and CE performance

- Collaboration with the government helps to change the relations from command and control to a mutual relation with the common objective

- Collaboration with clients and suppliers who are committed to the pursue of sustainability and CE objectives can trigger the organization's adoption of higher standards
- Can increase costs in the organization (2)

- Legal troubles could happen (IP protection, trade secret)

- Can harm the organization's sustainability

- Can lead the organization to neglect cross-departmental cooperation and focus only on external collaboration

- Can challenge the independence of the organization

- Inconsistent goals among partners may lead to unsuccessful collaborations

- Internal conflicts may arise

Table 7. SWOT table presenting the respondents' comments on the value optimization principle.

\begin{tabular}{|c|c|}
\hline \multicolumn{2}{|c|}{ Value Optimization } \\
\hline Strengths: & Weaknesses: \\
\hline $\begin{array}{l}\text { Helps the organization to reconsider what is } \\
\text { waste, and how to generate less waste in terms } \\
\text { of resources and energy (3) } \\
\text { - The nature of this principle is cost-saving } \\
\text { - The nature of this principle is } \\
\text { environmental sustainability } \\
\text { - Value optimization is easier to implement when } \\
\text { dealing directly with raw materials } \\
\text { - Underlies responsible purchasing } \\
\text { The management can easily understand the } \\
\text { potential of this principle and support } \\
\text { its implementation }\end{array}$ & 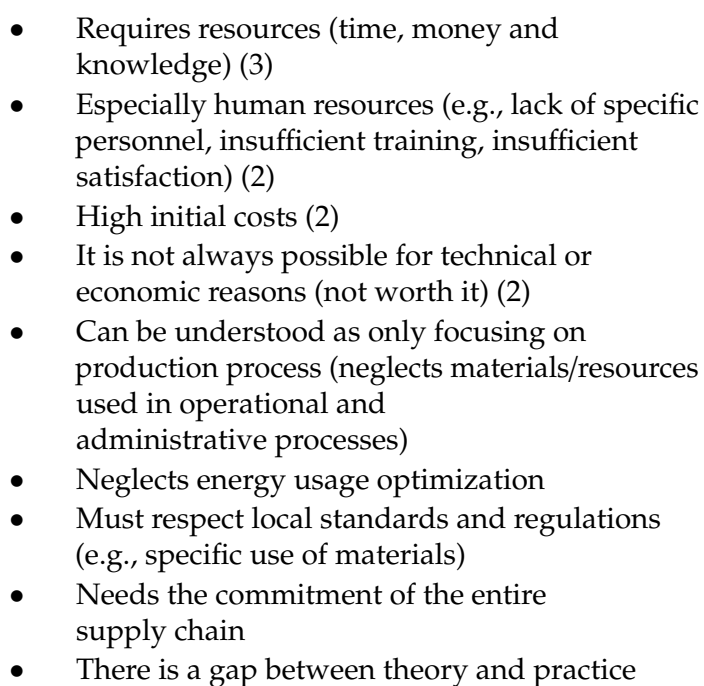 \\
\hline
\end{tabular}


Table 7. Cont.

\begin{tabular}{|c|c|}
\hline \multicolumn{2}{|c|}{ Value Optimization } \\
\hline Opportunities: & Threats: \\
\hline $\begin{array}{l}\text { - Can lead to many customers-related benefits } \\
\text { (e.g., satisfaction, attraction, gaining trust) (3) } \\
\text { - Can leads to an optimized value of products, } \\
\text { - } \quad \text { Hemponents and materials along its lifecycle (3) } \\
\text { of CE and implement it (3) } \\
\text { - } \quad \text { Favors collaborations (2) } \\
\text { - } \quad \text { Cost-reduction opportunities (2) } \\
\text { - } \quad \text { Leads to the best use of materials and labor } \\
\text { - Can bring internal employees-related benefits } \\
\text { - } \quad \text { Improves enhance confidence and participation) } \\
\text { - } \quad \text { Lead to the protection of the environment }\end{array}$ & $\begin{array}{l}\text { Potential conflict between value optimization } \\
\text { and business profit (3) } \\
\text { - Customers-related threats (e.g., won't buy the } \\
\text { product anymore, lack of trust) (2) } \\
\text { - Lack of communication between the parties of } \\
\text { the value chain, mining the implementation of } \\
\text { the principle } \\
\text { Lack of leadership support, hindering the } \\
\text { implementation of the principle } \\
\text { - Value optimization is not always } 100 \% \text { effective, } \\
\text { there is a certain degree of uncertainty }\end{array}$ \\
\hline
\end{tabular}

Table 8. SWOT table presenting the respondents' comments on the transparency principle.

\begin{tabular}{|c|c|}
\hline \multicolumn{2}{|c|}{ Transparency } \\
\hline Strengths: & Weaknesses: \\
\hline $\begin{array}{l}\text { Brings internal benefits (availability of } \\
\text { information, greater awareness and } \\
\text { collaboration) (4) } \\
\text { - Leads to the adoption of official communication } \\
\text { channels making information more reliable } \\
\text { - Easy to apply to CE aspects if already } \\
\text { considered as basic principle in the organization }\end{array}$ & $\begin{array}{l}\text { Depends on the availability of information (e.g., } \\
\text { sustainability-related, safety-related, CE-related, } \\
\text { end-of-life-related information) (4) } \\
\text { - } \quad \text { Internal factors (e.g., lack of transparency } \\
\text { management, lack of a dedicated department) can } \\
\text { limit the implementation of transparency (3) } \\
\text { - Transparency is dependent on law requirements (e.g., } \\
\text { small number of times in which disclosure is } \\
\text { compulsory, not compulsory to disclose information } \\
\text { for private companies) (2) } \\
\text { - Depends on external factors (suppliers refuse to } \\
\text { disclose information) (2) } \\
\text { Disclosure of information requires the } \\
\text { implementation of a monitoring system able to collect } \\
\text { and analyse data } \\
\text { Driven only by customer demand, no real } \\
\text { internalization by the organization } \\
\text { - Lack of knowledge on how to } \\
\text { implement transparency }\end{array}$ \\
\hline
\end{tabular}

Opportunities:

Threats:

- $\quad$ Being transparent may lead external actors to better understand the organization (4)

- Can enhance communication (2)

- Can increase investments (2)

- Can render the organization able to attract the attention of external actors (2)

- Conveys a positive image of the organization

- Enhances the organization's competitiveness

- Can lead to new cooperation opportunities

- Helps the organization avoiding local residents' complaints

- Can increase trust and motivate other actors in the supply chain to adopt more transparent measures
- Increased exposure and therefore vulnerability for the organization (2)

- $\quad$ The organization might not be able to keep up with transparency regulations because they change very quickly and are more and more stringent

- Unforeseeable factors (e.g., competency of the writer of the report, report model, writing style can damage the reputation and business of the organization)

- $\quad$ Being more transparent can turn out to be against business strategy

- $\quad$ Might underlie legal concerns (e.g., IP and trade secrets may be in danger)

- Competitive environment due to the fast-paced technological progress limits transparency

- Releasing information may lower the competitive advantage of the organizations 


\subsection{Self-Assessment Survey Results}

\subsubsection{Overall Results}

Overall, the results of the self-assessment survey (Figure 3) provided an optimistic outlook. Out of the 456 answers that were collected (19 for each of the 24 questions), $30(6.6 \%)$ and $250(54.8 \%)$ were respectively in strong agreement and agreement with the corresponding statements, $125(27.4 \%)$ were neutral, 50 (11\%) were in disagreement, and only one (0.2\%) was in strong disagreement. However, results in all six principles seem to indicate that there is a gap between beliefs and commitments, and their translation into concrete actions.
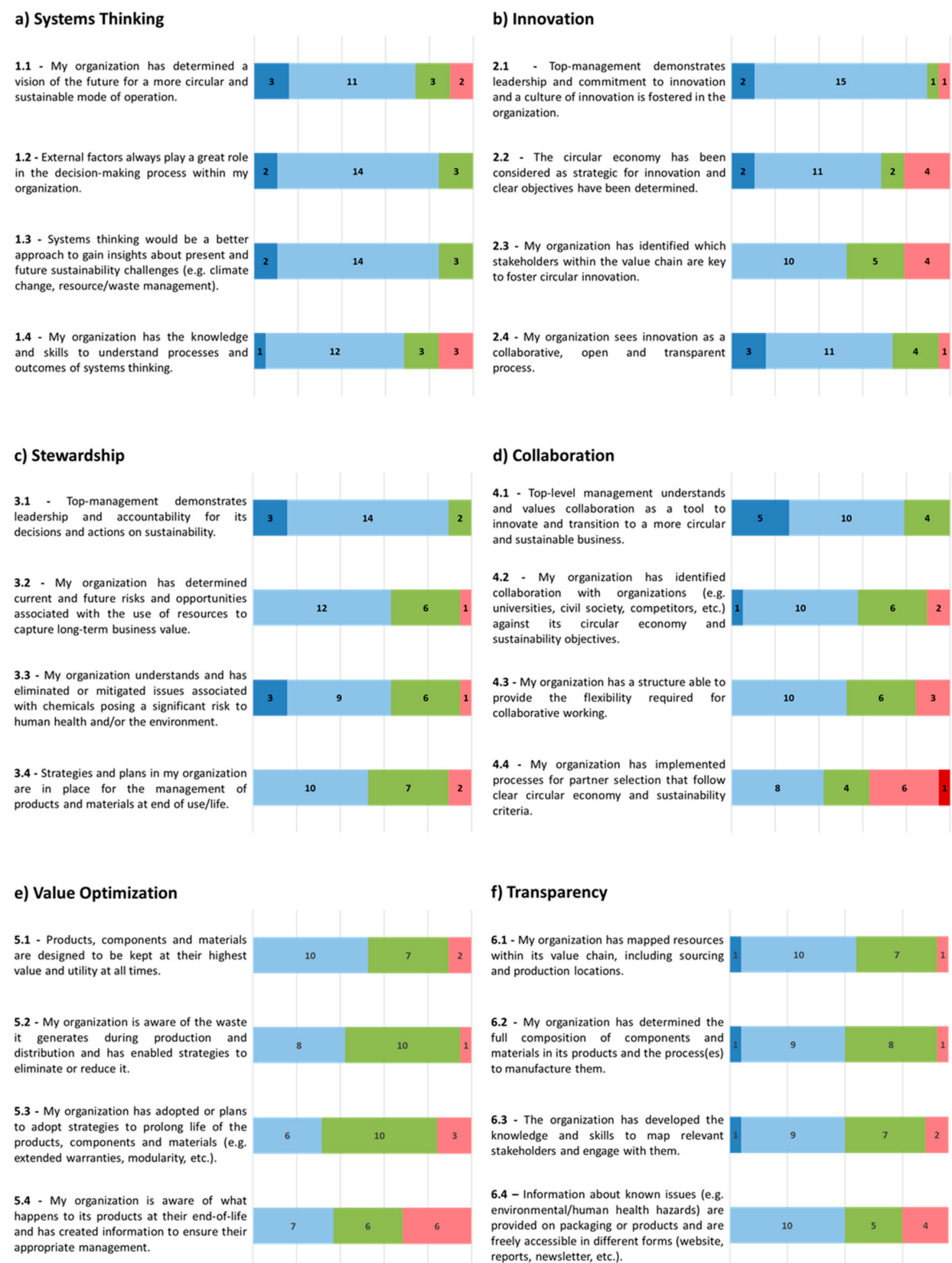

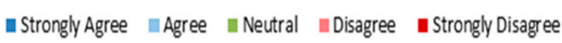

Figure 3. The graphs describe the self-assessed opinions of companies towards the six principles (a to f) of the CE outlined by the standard BSI BS8001:2017. The numbers on the bars indicate the number of respondents for each given opinion. 
Respondents were most in agreement with the statements of the systems thinking principle. This outcome is very significant since not only its adoption is now required in the most modern management standards (e.g., ISO management systems), but also because companies now start to see themselves as part of a more complex system whose health has effects on the survival of the company itself.

On the other hand, respondents were most in disagreement with the statements of the value optimization and collaboration principles. Both principles are at the core of the $\mathrm{CE}$ and can be of difficult application for companies given their challenging nature. Value optimization may require critical reconsiderations in the way products, processes, and revenue streams are conceived. These changes often entail significant risks and may require a considerable amount of resources and skills in order to be designed and implemented successfully. Similarly, collaboration, both internal and external, must build upon a joint approach and mutual trust, which can be hindered by barriers such as internal silos, lack of transparency and responsibility, or poor planning and management.

The following sections from Section 3.1.2, Section 3.1.3, Section 3.1.4, Section 3.1.5, Section 3.1.6 to Section 3.1.7 present and discuss in detail the results of the self-assessment survey for each principle of the BS 8001:2017.

\subsubsection{Systems Thinking}

The analysis of systems thinking as a principle of the CE included a statement about a vision of the future for a more circular and sustainable mode of operation (S1.1), one about the importance of external factors in the decision-making process (S1.2), one about the usefulness of a systems thinking approach to gain better insights about sustainability challenges (S1.3), and one about the necessary skills and knowledge to understand and implement systems thinking within the company (S1.4).

In all four statements, the scores were very positive. The statement that received the highest score was S1.3. The existing scientific literature supports this result as it points out that systems thinking approaches are needed for the development of sustainability oriented business models (SBMs) [86] and the application of more sustainable practices [87].

The statement that received the lowest score was S1.4. The result suggests that, despite the positive opinion about systems thinking as a useful principle for a more circular and sustainable mode of operation, companies do not always have the knowledge and skills that are necessary to implement it. This educational gap is reflected in Beasley [88], which indicates that barriers to the adoption of systems thinking can be of human (e.g., the inability to understand the dynamics of systems), organizational (e.g., lack of flexibility), and engineering-nature (e.g., necessary training to apply with confidence system-engineering techniques).

Statements S1.1 and S1.2 suggest that most of the respondents' companies have started to determine a vision for a more circular and sustainable mode of operation and identify those external factors that can affect their activities. These results are consistent with a 2018 survey by ING [89], where $62 \%$ of the surveyed U.S. companies stated their intention to move towards more sustainable and CE practices.

\subsubsection{Innovation}

The self-assessment survey on innovation as a principle of the $C E$ included a statement about the commitment of top management to innovate (S2.1), one about the importance of CE as a driver for innovation (S2.2), and two about the necessity to identify key stakeholders and establish collaborative processes to successfully promote innovation for the CE (S2.3 and S2.4).

Results indicate that respondents generally agreed on the assumption that innovation is a fundamental principle of the CE. The statement that received the highest score was S2.1. In their research, $\mathrm{Xu}$ and Bai [90] explain that managers in Chinese private companies tend to engage in maintaining a certain level of internal satisfaction, pursuing innovative decisions, improving the sustainable innovation of the company, and enhancing motivation and enthusiasm by encouraging innovation. However, statement S2.2 shows that this commitment does not always translate into action. 
The number of respondents having a neutral or discordant opinion about setting clear objectives for $\mathrm{CE}$ innovation amounted to six (two neutral and four in disagreement). Innovation can be driven by many factors, not only by CE or sustainability drivers. An additional comment also explained that the company's leadership considered $\mathrm{CE}$ as a driver for business innovation, but the management decided to maintain the original business model because of the associated risks and uncertainties of transforming it.

The statement that received the lowest score was S2.3. If analysed jointly with the results of S2.4, it can be observed that once again there is a gap between beliefs and commitments, and real actions. Results of our study indicate that most respondents strongly agree (3) or agree (11) on innovation being a collaborative process (S2.4), but only half of them have identified which stakeholders need to be involved in order to promote innovation (S2.3). However, the involvement of internal and external stakeholders in the implementation of innovative CE strategies remains an essential aspect that companies should address, as documented in the scientific literature [91], especially within the textile sector $[92,93]$.

\subsubsection{Stewardship}

The analysis of the stewardship as a principle of the CE included a statement about the leadership and accountability of top management for its decisions and actions on CE and sustainability (S3.1), and three about the identification of risks and opportunities and implementation of measures associated to the use of resources (S3.2), management of chemicals posing human health and environmental risk (S3.3), and management of produces and materials at their end-of-life (S3.4).

The scores were mixed, suggesting that not all respondents' companies have taken consistent actions in the direction of stewardship. The statement that received the highest score was S3.1. Consideration of sustainability issues, together with ethics and responsibility, is one of the most recurring aspects in modern corporate management [94], and our results highlight how the respondents' companies seem to have assimilated this concept.

Opinions about S3.2 show that most respondents' companies have determined risks and opportunities associated with the use of resources. Additionally, one respondent stated that their company is currently trying to conduct the mapping of resources along the entire supply chain in order to identify measures that can reduce or even eliminate the use of raw materials. For example, the company started reducing plastic packaging both internally and along its supply chain. Another respondent indicated that their company is currently performing life cycle assessment (LCA) study to identify those materials that cause the most significant environmental impacts and evaluate opportunities to replace them. In this sense, LCA can be a handy tool for companies to understand and manage the upstream and downstream environmental impacts of a product and the materials of which it is made [95].

Results of S3.3 show that most of the interviewed companies understand and have taken actions to eliminate or mitigate issues associated with chemicals potentially dangerous to human and environmental health. The statement that received the lowest score was S3.4, indicating that half of the respondents' companies have not taken measures to manage their products once they reach their end-of-life stage.

\subsubsection{Collaboration}

The analysis of collaboration as a principle of the CE included a statement about collaboration as a tool for top management to innovate and foster the transition toward a CE (S4.1), one about the establishment of collaborative relationships with companies in order to achieve CE objectives (S4.2), one about the flexibility of the company's structure that can support collaboration (S4.3), and one about the use of CE and sustainability criteria to select partners for collaboration (S4.4).

Even in this case, it is possible to observe a gap between belief and commitment of a company (S4.1), and the actions that have been implemented (S4.2, S4.3, S4.4). This outcome is corroborated by 
an additional comment provided by one respondent stating that "internal and external collaborations can rapidly promote $\mathrm{CE}$, but, at the same, being able to enable such collaborative practices can be extremely difficult for companies, especially if these practices aim at creating multiple collaborations along the entire supply chain."

The statement that received the highest score was S4.1, with five respondents who strongly agreed and ten who agreed. This result confirms the fact that the value of collaboration is necessary in order to build circular modes of operation, as described in research in both developed and developing countries [96].

The remaining statements received mixed opinions. Based on the results of S4.2, eight respondents companies seem not to have taken full measures to identify stakeholders that can support them in reaching the CE and sustainability objectives. Similarly, as shown in S4.3, nine respondents are neutral or do not agree on their company having a structure that is flexible enough to adopt collaborative working practices. Finally, the results of S4.4 show that only eight respondents' companies use sustainability and CE criteria to select partners for collaborations. This statement received the only opinion in strong disagreement among the entire self-assessment survey.

\subsubsection{Value Optimization}

The analysis of value optimization as a principle of the CE included a statement about the design of products and components in order to keep the value of materials at their highest at all times (S5.1), one about the generated waste and strategies to reduce or eliminate it (S5.2), one about strategies to prolong the life of products, components, and materials (S5.3), and one about the awareness of a company about the end-of-life phase of its products (S5.4).

In all four statements, scores did not reach an explicit agreement. The statement that received the highest score was S5.1; this result is somehow surprising, but it can be explained by the fact that the respondents evaluated the highest value of their materials and products in the context of the current economy, which does not favour $\mathrm{CE}$ practices such as repairability, longer lifetime, and reuse.

The statement that received the lowest score was S5.4, regarding the awareness of the company of what happens to its products at their end-of-life stage and the implementation of measures for their appropriate management. One additional comment pointed out that the respondent's company is not aware of the end-of-life fate of its products and that they are likely thrown away after use. This result confirms the general view among the respondents that principles such as systems thinking, stewardship, and value optimization are values to strive for, but, at least for now, companies struggle to translate them into concrete actions.

Statement S5.2 highlights how most respondents are scarcely or entirely not aware of the amount and type of waste generated during the production and distribution phases, and their companies have not established enough strategies to eliminate or reduce this waste. The majority (11) expressed a neutral (10) or in disagreement (1) opinion. Transitioning to CE practices requires commitment to improved waste management within the company. However, this can be a difficult task to accomplish due to burdensome pre-existing strategies, but most importantly, because of the lack of top-down leadership, innovative ideas, or a precise starting point [97].

Statement S5.3 provided similar results, with most respondents' companies not having adopted or planned to adopt measures to increase the lifetime of their products. These measures often consist of changing the business model of the company, which affects the way the company makes a profit and the distribution of profits over time. Therefore, given the risks and commitment that these transformations imply, top management can be easily discouraged from pursuing these actions. One respondent commented that their company extended the warranties of some of its products up to five years. Even though the reason behind that was to highlight the quality of the product, it is undeniable that a longer-lasting product also has a positive effect on the environment. 


\subsubsection{Transparency}

The Transparency principle analysis included a statement about mapping the resources within the supply-chain (S6.1), one about determining the components and materials of products and processes to manufacture them (S6.2), one about the mapping of stakeholders and strategies to communicate with them (S6.3), and one the communication of information about known issues related to sustainability aspects (S6.4).

Scores did not reach an explicit agreement among respondents in all four statements. The statement that received the highest score was S6.1. Eleven respondents agreed, seven had a neutral opinions, and one respondent disagreed. Together with S6.2, results suggest that companies are becoming more aware of the necessity of transparency among supply chains to effectively transition to a more circular and sustainable mode of operation and, therefore, actions towards this outcome are being taken.

Results of statement S6.3 show that a slight majority of the respondents' companies have the necessary knowledge and skills to map the relevant stakeholders and engage with them. Being able to map relevant stakeholders provides a useful way to understand the type of communication and degree of transparency that a company can have. Stakeholder management plays a crucial role in the success of a project, in which trust also has a dominant role. In this sense, de Oliveira et al. [98] identifies that stakeholder management and the degree of trust in a finished project are related. In one additional comment, a respondent stated that the company is trying to improve its transparency by requesting its suppliers to be transparent about the materials and chemicals used in the final products and about the manufacturing processes. Besides, the company recently issued its first corporate social responsibility (CSR) report, where a series of sustainability information facts was made available to stakeholders.

The statement that received the lowest score was S6.4, concerning the availability of information on the issues related to the company's products or services. An additional comment provided by one of the respondents can explain this result: many companies still adhere to the principle that what is not mandatory to communicate should not be delivered unless it demonstrates a definite advantage. Any information that is disclosed carries an inherent potential risk on reputation and competitive advantage for the company.

\subsection{SWOT Survey}

\subsubsection{Overall Results}

The SWOT survey reflects a positive perspective of respondents regarding CE in terms of opportunities, as well as a keen awareness of weaknesses associated with its adoption. This description applies especially to the principles of innovation, collaboration, value optimization, and transparency. By analysing the six SWOT analyses in this section of the paper, it is evident how the implementation of CE principles affects several areas and operations of a company, be it positively or negatively. Figure 4 provides a rough visualization of the perception of each dimension of the SWOT analysis, showing the number of comments shared by respondents for each criterion. The following sections from Section 3.2.2, Section 3.2.3, Section 3.2.4, Section 3.2.5, Section 3.2.6 to Section 3.2.7 present and discuss in detail the results of the SWOT analysis for each principle of the BS 8001:2017. 


\begin{tabular}{|c|c|c|}
\hline & Strengths & Weaknesses \\
\hline Systems Thinking & 000 & 0000000 \\
\hline Innovation & 000 & 0000000 \\
\hline Stewardship & 00000 & 0000000 \\
\hline Collaboration & 0000000 & 000000000 \\
\hline Value Optimization & 000 & 000000000 \\
\hline \multirow[t]{2}{*}{ Transparency } & 00 & 0000000 \\
\hline & Opportunities & Threats \\
\hline Systems Thinking & 00000 & o \\
\hline Innovation & 00000000000 & 000000 \\
\hline Stewardship & 0000000 & 00000 \\
\hline Collaboration & 000000000000000000 & 0000000 \\
\hline Value Optimization & 0000000000 & 00000 \\
\hline Transparency & 000000000000 & 0000000 \\
\hline
\end{tabular}

Figure 4. Number of different comments for each principle provided by the respondents in the SWOT analysis.

\subsubsection{Systems Thinking}

Overall, respondents distinguished more weaknesses (7) than strengths (3). Five different types of opportunities were identified, but only one threat was pointed out. The fact that participants were able to locate more barriers than enablers of systems thinking suggests that companies are still insecure about its implementation, as well as about the meaning of the principle itself. Therefore, they tended to focus more on the difficulties raised by systems thinking rather than the positive aspects and the opportunities brought by its implementation.

Regarding strengths, six respondents thought that systems thinking serves as guidance, principle, target, and strategy for implementing CE into companies. Participants also pointed out the fact that small companies can apply this principle more quickly because of the lower number of elements and connections in the system. In this regard, Sun et al. [99] state that systems thinking knowledge can: (a) equip small companies with a holistic view that allows for an understanding of the connectedness and interaction of components within the system; (b) motivate the adoption of qualitative systems thinking tools that can be used to unravel complex issues challenging to understand.

The main weakness concerned the need for financial and human support. Human resources play a crucial role in the implementation of systems thinking because it requires at least a basic understanding of the topic, which is not an ordinary skill among employees. Even business managers struggle in developing systems thinking skills since the educational system still focuses on linear thinking and analysis [99]. Respondents also stated that the lack or weak application of a management system in the company could hinder the use of systems thinking. A management system helps companies in outlining their activities and interactions with the external parts of the system, which are necessary aspects to understanding how the business system works. Respondents highlighted the lack of standard methods on how to adopt systems thinking profitably. Despite the lack of standards, different tools can be applied. Examples are value mapping [100], causal loop diagrams (CLDs), and system archetypes [101].

Respondents identified opportunities, both internal and external, to the company. Systems thinking can improve the competitiveness of a company by enhancing relationships with stakeholders, triggering innovation, and stimulating new business opportunities that reflect the unique challenges of this century. Finally, systems thinking could lead a company to change its management process. On this subject, Bruni et al. [102] explain the contribution of systems thinking within marketing and management in companies.

The only identified threat was the potentially small economic benefit brought by systems thinking that may justify the investment to acquire the necessary skills and knowledge.

Table 3 portrays the SWOT analysis for the systems thinking principle. 


\subsubsection{Innovation}

Overall, respondents identified an even number of positive (14) and negative aspects (13). In this sense, respondents proved the fact that innovation is an important business driver, but there are still many barriers that need to be challenged before profiting from it.

Among respondents, innovation was mainly considered as an organizational strategy that can quickly gain support from the top management. Furthermore, being innovative also means being able to maintain or even increase competitiveness, especially against those companies that do not innovate [103].

On the other hand, innovating is not an easy task. First, it requires resources in terms of time, finances, knowledge, and support. This explains why there seems to be an evident gap between theory and real application of innovation. Also, companies' activities are driven by customers' requirements, which do not always allow innovation from a CE perspective. These claims are supported by de Jesus [104], who suggests that most consumers are not interested in circular products but focus more on the cost-quality ratio.

Additionally, respondents stated that product innovation does not always bring social and environmental benefits. However, Garcia-Muiña et al. [95] found out that in a manufacturing milieu, eco-design (which can be seen as a tool for CE innovation) is the enabler of the equilibrium between the system's regenerative potential, and environmental and socio-economic sustainability. Finally, innovation from a single company is often not enough and should happen at the supply chain level to have meaningful effects.

In terms of opportunities, respondents said that innovation can inspire new ideas and promote the transformation of consumption and production to a more cyclical and sustainable business model. Eco-innovation helps companies to "close the loop" of materials and recover value from waste [91]. Participants pointed out the necessity to introduce supporting tools and technologies to facilitate research and development and drive companies to design products that fit the CE principles. Innovation can also enable the attraction and retainment of talented personnel and management team, as well as funds. Moreover, innovation promotes cooperation and vice versa. Hong et al. [105] show that collaborative innovation has a significant positive effect on innovation performance. Innovation could also trigger the creation of new patents, and employees could be motivated by gaining recognition for their innovative ideas.

Regarding threats, the most relevant fear was that innovation would not bring the expected economic benefits. However, existing research affirms that innovative activities are likely to determine the success of the business while ensuring its financial stability and survival [103]. Another threat was that competitors could copy innovative ideas, thus reducing the duration of the competitive advantage. However, McGrath et al. [106] affirm that innovation means to change the existing combinations of resources in the company, which is something difficult to imitate. One respondent added that innovation is a competition among other players. As a result, the competition might be lost, with consequent effects on the finances and reputation of the company. For this reason, companies either might prefer not to be first movers or might prefer the traditional mode of operations instead of innovating because the risks are already known and can be controlled [104]. Finally, innovation could end up being not fast enough, especially in a fast-changing market.

Table 4 portrays the SWOT analysis for the innovation principle.

\subsubsection{Stewardship}

Overall, the SWOT analysis of the stewardship principle provided a balanced overview of both positive and negative feedback, indicating that respondents recognize the benefits and opportunities that could result from being accountable for their actions, and at the same time, they are also aware of the weaknesses and threats that the application of this principle might generate.

Regarding strengths, respondents believed that stewardship can reinforce the commitment and leadership for the implementation of the CE. Stewardship is also ubiquitous as it can be shared or 
owned by individuals, communities, or networks of actors [107], and can be implemented by large, medium, and small companies. Additionally, stewardship can push employees to take responsibility and become leaders. People in the company who pursue stewardship as a principle usually have a high sense of commitment and a sense of shared ownership, which can also trigger an increased sense of leadership and inspiration towards colleagues [108]. Finally, stewardship can help companies to understand external factors better, enabling them to deal with the associated uncertainties.

In terms of weaknesses, stewardship requires awareness and resources (e.g., trained people, management systems, tools). Also, stewardship ends where the company does not have control over its outcomes (e.g., the ability to influence suppliers). Another aspect considered as a weakness by respondents is that stewardship requires effective communication between the departments across the value chain and, at the same time, depends to a great extent on top management's decision-making. Finally, stewardship is not always valued by customers, especially in periods of economic recession when they focus mostly on the quality-price ratio.

Stewardship can become an opportunity to satisfy customers' demands about CSR and CE practices. By being responsible for its activities, a company can learn to manage its impacts and, by doing so, become more reliable and attractive for customers, thus increasing financial benefits. Guimaraes and Sato [109] found evidence that companies with higher degrees of environmental stewardship derived more significant business benefits. Moreover, participants stated that through increased stewardship, companies can interact with different stakeholders such as universities, professionals, NGOs, local and national governments, as well as the society itself. Stewardship actions can be carried out by multi-stakeholder partnerships [107].

On the other hand, stewardship requires consistency through time, which can turn out to be challenging to perform in an environment with high staff turnover and a complex organizational structure. Moreover, stewardship is challenging to achieve if the consumer is not properly using a product and discarding it at its end-of-life phase. This suggests that companies should invest in consumer awareness and incentives that guarantee the effectiveness of its stewardship commitments. Finally, respondents feared that environmental stewardship in the name of the CE can be misleading for the company and, as a result, lead to bad decisions that might result in severe damages for the business.

Table 5 portrays the SWOT analysis for the stewardship principle.

\subsubsection{Collaboration}

In terms of collaboration, respondents identified several opportunities. They also identified significant weaknesses and threats that could arise. These results suggest that collaborations can be profitable but that they are not always a synonym of success. Collaborations hide many risks that companies have to evaluate carefully through tools such as the standard ISO 44001:2017 on Collaborative Business Relationship Management Systems [110], which helps companies assess whether or not to start internal and external collaborations.

Regarding strengths, collaboration can reduce the risk for a company to make mistakes and facilitate interactions with internal and external stakeholders. It is expected that collaborative governance will drive to better decisions and policy results [111]. Collaborative activities generate a flow of knowledge among the companies; in this way, companies learn from each other, assimilating new notions that may help them avoid making risky choices. Nonetheless, internal actors would gain new knowledge and will better understand the organizational strategies regarding CE and sustainability. Collaboration is seen as complementary to knowledge management; Senge [112] states that knowledge can be managed by focusing on collaboration and tools that facilitate collaboration.

The main weakness described the lack of teamwork as detrimental to collaboration. Therefore, communication and coordination must be in place to reach the expected outcomes. Coordination is a prerequisite that companies need to develop before engaging in any type of collaboration [113]; otherwise, it could lead to the failure of the cooperation itself [114]. 
Three respondents commented that not all companies have the possibility to establish fruitful collaborations. This is often caused by the demanding resources (time, money, expertise) that are needed, which may discourage the top management from approving any sort of collaboration, especially those that do not guarantee a short-term financial outcome. Freitas et al. [115] describe how the high initial investment can be seen as a barrier when implementing cooperation, especially for small businesses. A company's structure can be another barrier; rigid organizational structures and processes can hinder collaborations [115]. Finally, different levels of knowledge about the CE and sustainable development may act as a barrier as well.

Collaborations can be opportunities for improvement in many fields (financial situation, efficiency, and knowledge) as well as leverage for competitive advantage. Companies can integrate their partners' knowledge and experience into their expertise [116]. Collaborations can create additional value and be a way for the company to gain external support and resources. Finally, they can also bring internal changes by creating a flexible structure in the company. Hanna [117] points out that collaboration is positively linked to flexibility. Also, Chou [116] suggests that logistic services, in particular, are rendered more flexible through collaboration.

Collaboration can also generate the change of a company's business model (BM), an essential aspect in the context of the CE. Additionally, collaborations with clients and suppliers who are committed to sustainability and CE practices can push the company to adopt more stringent and practical standards. Finally, internal coordination and cooperation can provide a better knowledge and understanding of the company's sustainability aspects, while collaborating with academies and pioneers of the $\mathrm{CE}$ drives the company towards the acquisition of the leadership and stewardship necessary to improve sustainability and CE performance.

The most concerning threat was that collaborations may increase expenses for the company. Also, inconsistent goals may lead to unsuccessful collaborations, potentially causing legal repercussions (e.g., litigation over IP protection and trade secrets). Studies point out that goal alignment between partners is a core feature in collaboration $[114,118]$. Also, respondents stated that external collaborations might lead to neglect cross-departmental cooperation, leading to internal conflicts. Lastly, an unsuccessful collaboration may harm the company's reputation, hindering its financial sustainability, and challenge the independence of the company. A brilliant example of a fifty-year-long collaboration that failed after external stakeholder intervention is the toy company LEGO Group and oil company Royal Dutch Shell collaboration, which ended as a consequence of Greenpeace exposing in the media the controversy of the branding partnership, which contrasted with LEGO Group's concerns about the environment and its related sustainable actions [119]. LEGO's partnership with Shell was inconsistent with its corporate values [120], which ended up creating confusion between the toy company's stakeholders and damaging the reputation and brand image of the company [119].

Table 6 portrays the SWOT analysis for the collaboration principle.

\subsubsection{Value Optimization}

Several insights can be drawn from the SWOT analysis of the value optimization principle. All four quadrants have received several comments, suggesting that companies have mixed opinions about this principle.

The foremost identified strength was that value optimization forces the company to reconsider what is waste and how to generate less of it, both in terms of resources and energy. One respondent affirmed that value optimization might be more natural to implement for companies dealing directly with raw materials. Another strength was the environmentally friendly and cost-saving nature of the principle. Furthermore, management can easily understand the potential of this principle and tends to support its implementation.

The most relevant identified weakness of value optimization was that it requires resources and high initial costs. Furthermore, the internal knowledge and expertise of the company might be a source of failure: insufficient training and the lack of specialized personnel might create unfavourable 
conditions for value optimization. More respondents stated that value optimization is a very generic term and does not help to identify how to optimize the value of a company's output. For example, one respondent stated that the principle tends to neglect energy usage optimization. In this regard, studies show that it is not always clear how resource efficiency should be weighed against energy efficiency [121]. Furthermore, a gap between theory and practice seems to exist. In fact, value optimization is not always possible for technical or financial reasons. Finally, to be effective, value optimization needs to happen along the entire supply chain and not pursued only by one actor.

Respondents identified various opportunities. Value optimization can lead to customer-related benefits and render the company up-to-date with the related industry market trends. It can also bring cost-reduction benefits and lead to the best use of materials and labour, as well as better management of waste and resources. Finally, it intrinsically helps companies to pursue the implementation of CE and environmental protection practices.

Among the identified threats, the most relevant was the possibility of a conflict between value optimization and business profit. Moreover, value optimization is not always $100 \%$ effective; there is a certain degree of uncertainty. Another threat referred to the fact that there could be a lack of proper communication between the parties of the value chain, mining the implementation of the principle itself.

Table 7 portrays the SWOT analysis for the value optimization principle.

\subsubsection{Transparency}

Regarding the transparency principle, respondents did not identify a consistent number of strengths (3), but different opportunities were recognized (12). Weaknesses and threats show that transparency does not always bring positive results. As respondents noticed, many potentially negative impacts can be generated by the adoption of this principle.

Regarding strengths, transparency has the capability of bringing internal benefits to the company, such as the availability of relevant information, greater awareness, and better collaboration among the staff. Berggren and Bernshteyn [122] state that the level of transparency at which the organizational strategy is communicated to the personnel has the potential to impact the overall performance of the company; if the individual goals of the employees are not aligned with the strategy of the company, this will lead to poor performance. In fact, it would be easier to implement CE aspects if transparency was already considered as a fundamental principle in the company and the whole supply chain.

About weaknesses, transparency is dependent on the availability of information. If information is not gathered, it cannot be communicated. Moreover, the legal framework that regulates the disclosure of information in China is too weak. For example, the number of times that companies must disclose sustainability related details is too small. Additionally, private companies are not obliged to disclose information, and this does not encourage transparency in the Chinese private sector.

Moreover, the implementation of a higher level of transparency could be easily hindered by external actors such as suppliers who may refuse to disclose certain information. At the same time, internal factors also play a crucial role: a lack of adequate transparency of management or of a dedicated department aimed at the analysis of information before disclosure can affect the final quality level of transparency. In many cases, transparency is driven only by customer demand, resulting in the company not having a real internalization of the principle. Fernandez-Feijoo [123] highlights the fact that the company's level of transparency depends on the pressure of specific stakeholders in the industry, which confirms the fact that external pressure plays a crucial role in transparency adoption. Additionally, there could be a lack of knowledge within the company on how to implement transparency. This last point has been proven by studies that highlight how a company's features (e.g., size, industry type, and business location) can influence its transparency performance [124].

Respondents acknowledged that transparency could generate several opportunities. In the first place, being transparent can lead external actors to understand the company better and potential investors to increase investments towards it. It is shown that one of the benefits of reporting and 
disclosure is the growth of long-term investors [125]. Furthermore, opportunities for cooperation with stakeholders can rise. One respondent stated that being transparent helps the company to reduce complaints from the local community and enhances trust among costumers and other stakeholders. Finally, a more transparent behaviour can increase confidence and lead other actors in the supply chain to disclose more information.

Threats were also identified. Transparency could increase the vulnerability of a company. This feeling was widespread among practitioners, who believed that a high degree of transparency can turn out to damage their business strategy and competitiveness [126]. Technological progress could also hinder full transparency because of the fear of losing the technological advantage. The respondents also highlighted the fact that transparency may underlie legal concerns: IP and trade secrets can be in danger, and releasing important information increase the chances that other companies might try to replicate the company's business. Finally, by being transparent, the company tends to expose itself to the judgement of stakeholders. In this regard, the expertise and style of the PR staff and the type of the communication adopted by the company can turn out to be potential threats for its image and reputation.

Table 8 portrays the SWOT analysis for the transparency principle.

\section{Conclusions}

This explorative study adds further evidence to the existing literature about the $\mathrm{CE}$ and its implementation at the micro level of companies and organizations. Apart from a theoretical contribution, the results of the study can have positive practical implications for practitioners, researchers, and policymakers. The paper's findings can help sustainability and environmental managers to understand the importance of the CE principles better, develop ad hoc strategies for their implementation, anticipate potential difficulties and barriers, and maximize the benefits originating from the opportunities that the CE can bring to a company in both tangible (profits and savings) and intangible (brand recognition, reputation, innovation, collaboration) forms. The paper also provides a description of topics that companies need to consider to start their path to a circular model of operation. The results of this research are not characterized by generalizability [127]. Therefore, a higher number of case studies, along with the development of quantitative surveys, could provide a better understanding of the concept of $\mathrm{CE}$ and its principles and practices within Chinese companies. Moreover, a small number of companies did not allow us to analyse opinions by specific sizes or industry type (e.g., construction, textile, electronics), which would have been useful. Also, the SWOT analysis tool has limitations itself. Respondents simply identified the principle strengths, weaknesses, opportunities, and threats, but they received no guidance on what to do with the list. SWOT provided a map, but no guidance on the destination. Finally, the level of awareness of CE among the respondents was uneven and not possible to quantitatively address. This might have biased the results by highlighting the responses of the participants with more expertise. The above points would be worth addressing in future studies when more data are available. Accordingly, further qualitative analysis could be performed, as the topic of CE is still at its initial stages of implementation. Future studies could deepen the analysis by adding new categories of classification factors to the SWOT analysis (strengths, weaknesses, internal opportunities, internal threats, stimulants, counter stimuli, external opportunities, external threats), as proposed by Nazarko and colleagues [128]. Moreover, future research could analyse the different perceptions of CE principles in companies from other areas of the world and test whether the findings are in line with the results of this paper. Finally, the analysis of organizational and structural conditions that are needed within different industrial sectors to promote the implementation of CE principles and practices would be useful to assess.

Supplementary Materials: The following are available online at http://www.mdpi.com/2071-1050/12/3/832/s1.

Author Contributions: Conceptualization, M.P.; Data curation, M.P., I.T. and D.G.; Formal analysis, M.P. and D.G.; Funding acquisition, M.P.; Investigation, M.P.; Methodology, M.P.; Supervision, A.C., X.W., H.C. and A.M.; 
Writing-original draft, M.P. and I.T.; Writing-review \& editing, A.C., D.B. and X.W. All authors have read and agreed to the published version of the manuscript.

Funding: The research and the APC were funded by the RFIYS 2018 project "Methods and tools for the implementation and assessment of circular economy at the micro-level of companies and organizations in China," grant number 41850410494, National Natural Science Foundation of China.

Conflicts of Interest: The authors declare no conflict of interest.

\section{References}

1. Lieder, M.; Rashid, A. Towards circular economy implementation: A comprehensive review in context of manufacturing industry. J. Clean. Prod. 2016, 115, 36-51. [CrossRef]

2. Ghisellini, P.; Cialani, C.; Ulgiati, S. A review on circular economy: The expected transition to a balanced interplay of environmental and economic systems. J. Clean. Prod. 2016, 114, 11-32. [CrossRef]

3. Stahel, W.R. The circular economy. Nature 2016, 531, 435-438. [CrossRef]

4. Geissdoerfer, M.; Savaget, P.; Bocken, N.M.P.; Hultink, E.J. The Circular Economy-A new sustainability paradigm? J. Clean. Prod. 2017, 143, 757-768. [CrossRef]

5. McKinsey \& Company. McKinsey Center for Business and Environment; McKinsey \& Company: New York, NY, USA, 2016; p. 38.

6. EY. Are You Ready for the Circular Economy? The Necessity of an Integrated Approach; EY: London, UK, 2015.

7. Deloitte. Breaking the Barriers to the Circular Economy; Deloitte: New York, NY, USA, 2017.

8. Accenture. Circular Advantage. Accent. Strateg. 2014, 24. Available online: https://www.accenture. com/t20150523t053139_w__us-en/_acnmedia/accenture/conversion-assets/dotcom/documents/global/ pdf/strategy_6/accenture-circular-advantage-innovative-business-models-technologies-value-growth.pdf (accessed on 20 January 2020).

9. United Nations Sustainable Development Goals-Goal 12 Ensure Sustainable Consumption and Production Patterns. Available online: https://www.un.org/sustainabledevelopment/sustainable-consumptionproduction/ (accessed on 20 January 2020).

10. Suárez-Eiroa, B.; Fernández, E.; Méndez-Martínez, G.; Soto-Oñate, D. Operational principles of circular economy for sustainable development: Linking theory and practice. J. Clean. Prod. 2019, 214, 952-961. [CrossRef]

11. Kirchherr, J.; Reike, D.; Hekkert, M. Conceptualizing the circular economy: An analysis of 114 definitions. Resour. Conserv. Recycl. 2017, 127, 221-232. [CrossRef]

12. Ellen MacArthur Foundation. Foundation Towards a Circular Economy: Business Rationale for an Accelerated Transition; Ellen MacArthur Foundation: Cowes, UK, 2015; p. 20.

13. Merli, R.; Preziosi, M.; Acampora, A. How do scholars approach the circular economy? A systematic literature review. J. Clean. Prod. 2018, 178, 703-722. [CrossRef]

14. European Commission Circular Economy. Available online: https://ec.europa.eu/growth/industry/ sustainability/circular-economy_en (accessed on 7 September 2019).

15. European Commission. European Commission DIRECTIVE 2008/98/EC on Waste and Repealing Certain Directives; European Commission: Brussels, Belgium, 2008; pp. 3-30.

16. European Commission. European Commission Directive (EU) 2018/851 of the European Parliament and of the Council of 30 May 2018 Amending Directive 2008/98/EC on Waste (Text with EEA Relevance); European Commission: Brussels, Belgium, 2018; pp. 109-140.

17. European Commission. Closing the Loop-An EU Action plan for the Circular Economy. Communication from the Commission to the European Parliament, the Council, the European Economic and Social Committee and the Committee of the Regions; European Commission: Brussels, Belgium, 2015; p. 21.

18. European Commission. Commission Staff Working Document Accompanying The Document Report From The Commission To The European Parliament, The Council, The European Economic And Social Committee and The Committee of The Regions on The Implementation of The Circular Economy Actio; European Commission: Brussels, Belgium, 2019.

19. European Commission. Implementation of the Circular Economy Action Plan. Available online: https://ec.europa.eu/environment/circular-economy/index_en.htm (accessed on 20 January 2020). 
20. Liu, L.; Liang, Y.; Song, Q.; Li, J. A review of waste prevention through 3R under the concept of circular economy in China. J. Mater. Cycles Waste Manag. 2017, 19, 1314-1323. [CrossRef]

21. The Standing Committee of the National People's Congress. Circular Economy Promotion Law of the People's Republic of China; The Standing Committee of the National People's Congress: Beijing, China, 2008; pp. 1-11.

22. Standing Committee of the National People's Congress. Circular Economy Promotion Law of the People's Republic of China (2018 Amendment); The Standing Committee of the National People's Congress: Beijing, China, 2018.

23. Mathews, J.A.; Tan, H. Circular economy: Lessons from China. Nature 2016, 531, 440-442. [CrossRef]

24. Central Committee of the Communist Party of China. The 13th Five-Year Plan for Economic and Social Development of the People's Republic of China; Central Compilation Translation Press: Beijing, China, 2016; p. 219.

25. OECD China Economic Snapshot. Available online: https:/www.oecd.org/economy/china-economicsnapshot/ (accessed on 20 January 2020).

26. Zhu, J.; Fan, C.; Shi, H.; Shi, L. Efforts for a Circular Economy in China: A Comprehensive Review of Policies. J. Ind. Ecol. 2019, 23, 110-118. [CrossRef]

27. Hansor, R. What the China-US Trade War Means for Corporate Sustainability. Available online: https://www. eco-business.com/opinion/what-the-china-us-trade-war-means-for-corporate-sustainability/ (accessed on 16 August 2019).

28. Kuhn, B. Sustainable Development Discourses in China. J. Sustain. Dev. 2016, 9, 158. [CrossRef]

29. Beijing Review, King's College London. Communiqué of the Fifth Plenary Session of the 18th CPC Central Committee (Excerpts), Beijing, China, 9-12 November 2013. Available online: http://www.bjreview.com/Beijing_Review_and_Kings_College_London_Joint_Translation_Project/ 2015/201703/t20170321_800091799.html (accessed on 20 January 2020).

30. UNEP. Green water and green mountains are Jinshan and Yinshan: The "Thousand Village Demonstration and Ten Thousand Village Rehabilitation" project in Zhejiang China. Available online: https://www. unenvironment.org/zh-hans/xinwenyuziyuan/gushi/lushuiqingshanjiushijinshanyinshan (accessed on 20 November 2019).

31. Zhang, B. Market-based solutions: An appropriate approach to resolve environmental problems. Chin. J. Popul. Resour. Environ. 2013, 11, 87-91.

32. The Circulars. Available online: https://thecirculars.org (accessed on 16 August 2019).

33. Circle Economy. The Circularity Gap Report: An Analysis of the Circular State of the Global Economy; Circle Economy: Amsterdam, The Netherlands, 2018; p. 36.

34. United Nations Sustainable Development Goals. Available online: https:/sustainabledevelopment.un.org/ ?menu=1300 (accessed on 20 January 2020).

35. Wijkman, A.; Skånberg, K. The Circular Economy and Benefits for Society: Jobs and Climate Clear Winners in an Economy Based on Renewable Energy and Resource Efficiency; Club of Rome: Zurich, Switzerland, 2015; p. 59.

36. Geerken, T.; Schmidt, J.; Boonen, K.; Christis, M.; Merciai, S. Assessment of the potential of a circular economy in open economies-Case of Belgium. J. Clean. Prod. 2019, 227, 683-699. [CrossRef]

37. Wang, N.; Lee, J.C.K.; Zhang, J.; Chen, H.; Li, H. Evaluation of Urban circular economy development: An empirical research of 40 cities in China. J. Clean. Prod. 2018, 180, 876-887.

38. Fratini, C.F.; Georg, S.; Jørgensen, M.S. Exploring circular economy imaginaries in European cities: A research agenda for the governance of urban sustainability transitions. J. Clean. Prod. 2019, 228, 974-989.

39. Wang, N.; Lee, J.C.K.; Zhang, J.; Chen, H.; Li, H. Evaluation of Urban circular economy development: An empirical research of 40 cities in China. J. Clean. Prod. 2018, 180, 876-887. [CrossRef]

40. Mathews, J.A.; Tan, H.; Hu, M.C. Moving to a Circular Economy in China: Transforming Industrial Parks into Eco-industrial Parks. Calif. Manag. Rev. 2018, 60, 157-181. [CrossRef]

41. Neves, A.; Godina, R.; Carvalho, H.; Azevedo, S.G.; Matias, J.C.O. Industrial Symbiosis Initiatives in United States of America and Canada: Current Status and Challenges. In Proceedings of the 2019 8th International Conference on Industrial Technology and Management (ICITM), Cambridge, UK, 2-4 March 2019.

42. Association ORÉE. Le Recueil Des Démarches D' Écologie Industrielle et Territoriale; Association ORÉE: Paris, France, 2016. Available online: https://www.actu-environnement.com/media/pdf/news-26000-ecologieindustrielle-territoriale-2015.pdf (accessed on 20 January 2020).

43. Bassi, F.; Dias, J.G. The use of circular economy practices in SMEs across the EU. Resour. Conserv. Recycl. 2019, 146, 523-533. [CrossRef] 
44. Franco, M.A. Circular economy at the micro level: A dynamic view of incumbents' struggles and challenges in the textile industry. J. Clean. Prod. 2017, 168, 833-845. [CrossRef]

45. Schroeder, P.; Anggraeni, K.; Weber, U. The Relevance of Circular Economy Practices to the Sustainable Development Goals. J. Ind. Ecol. 2019, 23, 77-95. [CrossRef]

46. Murray, A.; Skene, K.; Haynes, K. The Circular Economy: An Interdisciplinary Exploration of the Concept and Application in a Global Context. J. Bus. Ethics 2017, 140, 369-380. [CrossRef]

47. Kalmykova, Y.; Sadagopan, M.; Rosado, L. Circular economy-From review of theories and practices to development of implementation tools. Resour. Conserv. Recycl. 2018.

48. Koppius, O.; Ozdemir, O.; van der Laan, E. Beyond Waste Reduction: Creating Value with Information Systems in Closed-Loop Supply Chains; ERIM: Rotterdam, The Netherlands, 2011.

49. Zink, T.; Geyer, R. Circular Economy Rebound. J. Ind. Ecol. 2017, 21, 593-602. [CrossRef]

50. Svensson, N.; Funck, E.K. Management control in circular economy. Exploring and theorizing the adaptation of management control to circular business models. J. Clean. Prod. 2019, 233, 390-398. [CrossRef]

51. Bocken, N.M.P.; de Pauw, I.; Bakker, C.; van der Grinten, B. Product design and business model strategies for a circular economy. J. Ind. Prod. Eng. 2016, 33, 308-320. [CrossRef]

52. Geissdoerfer, M.; Morioka, S.N.; de Carvalho, M.M.; Evans, S. Business models and supply chains for the circular economy. J. Clean. Prod. 2018, 190, 712-721.

53. Lüdeke-Freund, F.; Gold, S.; Bocken, N.M.P. A Review and Typology of Circular Economy Business Model Patterns. J. Ind. Ecol. 2019, 23, 36-61. [CrossRef]

54. Pieroni, M.P.P.; McAloone, T.C.; Pigosso, D.C.A. Business model innovation for circular economy and sustainability: A review of approaches. J. Clean. Prod. 2019, 215, 198-216. [CrossRef]

55. Upadhyay, A.; Akter, S.; Adams, L.; Kumar, V.; Varma, N. Investigating "circular business models" in the manufacturing and service sectors. J. Manuf. Technol. Manag. 2019, 30, 590-606. [CrossRef]

56. Ellen MacArthur Foundation. Circularity Indicators: Project Overview; Ellen MacArthur Foundation: Cowes, UK, 2015; pp. 1-12.

57. Moraga, G.; Huysveld, S.; Mathieux, F.; Blengini, G.A.; Alaerts, L.; Van Acker, K.; de Meester, S.; Dewulf, J. Circular economy indicators: What do they measure? Resour. Conserv. Recycl. 2019, 146, 452-461. [CrossRef] [PubMed]

58. Parchomenko, A.; Nelen, D.; Gillabel, J.; Rechberger, H. Measuring the circular economy-A Multiple Correspondence Analysis of 63 metrics. J. Clean. Prod. 2019, 210, 200-216. [CrossRef]

59. Saidani, M.; Yannou, B.; Leroy, Y.; Cluzel, F.; Kendall, A. A taxonomy of circular economy indicators. J. Clean. Prod. 2019, 207, 542-559. [CrossRef]

60. Niero, M.; Rivera, X.C.S. The Role of Life Cycle Sustainability Assessment in the Implementation of Circular Economy Principles in Organizations. Procedia CIRP 2018, 69, 793-798. [CrossRef]

61. The British Standards Institution. Framework for Implementing the Principles of the Circular Economy in Organizations_Guide; BSI Standards Limited: London, UK, 2017; ISBN 9780580926440.

62. ISO. ISO 26000:2010 Guidance on Social Responsibility; ISO: Geneva, Switzerland, 2010; pp. 1-117.

63. Sousa-Zomer, T.T.; Magalhães, L.; Zancul, E.; Campos, L.M.S.; Cauchick-Miguel, P.A. Cleaner production as an antecedent for circular economy paradigm shift at the micro-level: Evidence from a home appliance manufacturer. J. Clean. Prod. 2018, 185, 740-748. [CrossRef]

64. Frosch, R.A.; Gallopoulos, N.E. Strategies for Manufacturing Waste from one industrial process can serve as the raw materials for another, thereby reducing the impact of industry on the environment. Sci. Am. 1989, 261, 144-153. [CrossRef]

65. Lombardi, D.R.; Laybourn, P. Redefining Industrial Symbiosis. J. Ind. Ecol. 2012, 16, 28-37. [CrossRef]

66. Stahel, W.R. The Performance Economy, 2nd ed.; Palgrave Macmillan: London, UK, 2010; ISBN 0230584667.

67. Benyus, J.M. Biomimicry: Innovation Inspired by Nature; Harper Perennial: New York, NY, USA, 2002.

68. Braungart, M.; McDonough, W. Cradle to Cradle: Remaking the Way We Make Things, 1st ed.; North Point Press: New York, NY, USA, 2002; ISBN 0865475873.

69. Pauli, G. Blue Economy-10 Years, 100 Innovations, 100 Million Jobs; Paradigm Pubns: Taos, Mexico, 2010.

70. Tillman Lyle, J. Regenerative Design for Sustainable Development; John Wiley \& Sons, Inc.: Hoboken, NJ, USA, 1996.

71. Hawken, P.; Lovins, A.; Lovins, L.H. Natural Capitalism: Creating the Next Industrial Revolution, 1st ed.; US Green Building Council: Washington, DC, USA, 2000; ISBN 9780316353007. 
72. Floridi, L.; Cowls, J. A Unified Framework of Five Principles for AI in Society. Harv. Data Sci. Rev. 2019. [CrossRef]

73. Floridi, L. Translating Principles into Practices of Digital Ethics: Five Risks of Being Unethical. Philos. Technol. 2019, 32, 185-193. [CrossRef]

74. Circle Economy. Making Sense of the Circular Economy The 7 Key Elements. Available online: https://www.circle-economy.com/the-7-key-elements-of-the-circular-economy (accessed on 20 January 2020).

75. Antikainen, M.; Aminoff, A.; Paloheimo, H.; Kettunen, O. Designing circular business model experimentation-Case study. In Proceedings of the ISPIM Innovation Forum, Toronto, ON, Canada, 19-22 March 2017; pp. 1-14.

76. Ellen MacArthur Foundation Concept. What is a circular economy? A framework for an economy that is Restorative and Regenerative by Design. Available online: https://www.ellenmacarthurfoundation.org/ circular-economy/concept (accessed on 20 January 2020).

77. Weetman, C. A Circular Economy Handbook for Business and Supply Chains: Repair, Remake, Redesign, Rethink, 1st ed.; Kogan Page Ltd.: New York, NY, USA, 2016; ISBN 9780749476755.

78. Tonelli, M.; Cristoni, N. Strategic Management and the Circular Economy; Routledge: New York, NY, USA, 2019; ISBN 978-1-138-10363-4.

79. Likert, R. A technique for the measurement of attitudes. Arch. Psychol. 1932, 22, 1-55.

80. Van Vliet, V. SWOT Analysis. Available online: https://www.toolshero.com/strategy/swot-analysis/ (accessed on 27 July 2019).

81. Humphrey, A. SWOT Analysis for Management Consulting. SRI Alumni Newsl. 2005, 7-8. Available online: www.sri.com/sites/default/files/brochures/dec-05.pdf (accessed on 26 May 2014).

82. Pesce, M.; Shi, C.; Critto, A.; Wang, X.; Marcomini, A. SWOT analysis of the application of international standard ISO 14001 in the Chinese context. A case study of Guangdong Province. Sustainability 2018, 10, 3196. [CrossRef]

83. Bordignon, M.; Lhopital, V. SWOT Analysis of the ISO 14006 Application. A Practical Case and Its Consequences on Ecodesigned Products. In ED2E 2017: Eco-Design in Electrical Engineering; Springer: Berlin/Heidelberg, Germany, 2018; pp. 17-22.

84. Yang, D.; Wang, X.; Kang, J. SWOT Analysis of the Development of Green Energy Industry in China: Taking solar energy industry as an example. In Proceedings of the 2018 2nd International Conference on Green Energy and Applications (ICGEA), Singapore, 24-26 March 2018; pp. 103-107.

85. Iacondini, A.; Mencherini, U.; Morselli, L.; Passarini, F.; Vassura, I. Industrial Symbiosis In Italy As A Tool For Sustainability: Case Study Analysis And Replicability. Procedia Environ. Sci. Eng. Manag. 2014, 1, $19-24$.

86. Breuer, H.; Fichter, K.; Freund, F.L.; Tiemann, I. Sustainability-oriented business model development: Principles, criteria and tools. Int. J. Entrep. Ventur. 2018, 10, 256-286. [CrossRef]

87. Zhang, H.; Amodio-Calvo, J.; Haapala, K.R. A systems thinking approach for modeling sustainable manufacturing problems in enterprises. In Proceedings of the American Society for Engineerning Management (ASEM) 2013 Internation Annual Conference, Minneapolis, MN, USA, 3-5 October 2013; pp. 239-249.

88. Beasley, R. The Barriers to Systems Thinking. INCOSE Int. Symp. 2012, 22, 517-531. [CrossRef]

89. ING. Opportunity and Disruption: How Circular Thinking Could Change US Business Models; ING: Amsterdam, The Netherlands, 2018.

90. Xu, P.; Bai, G. Board Governance, Sustainable Innovation Capability and Corporate Expansion: Empirical Data from Private Listed Companies in China. Sustainability 2019, 11, 3529. [CrossRef]

91. Jakhar, S.K.; Mangla, S.K.; Luthra, S.; Kusi-Sarpong, S. When stakeholder pressure drives the circular economy. Manag. Decis. 2019, 57, 904-920. [CrossRef]

92. Staicu, D.; Pop, O. Mapping the interactions between the stakeholders of the circular economy ecosystem applied to the textile and apparel sector in Romania. Manag. Mark. 2018, 13, 1190-1209. [CrossRef]

93. Boiten, V.J.; Li-Chou Han, S.; Tyler, D. Circular Economy Stakeholder Perspectives: Textile Collection Strategies to Support Material Circularity; European Union's: Brussels, Belgium, 2017.

94. Laasch, O.; Conaway, R. Principles of Responsible Management: Glocal Sustainability, Responsibility, Ethics; Nelson Education: Scarborough, ON, Canada, 2015. 
95. Garcia-Muiña, F.E.; González-Sánchez, R.; Ferrari, A.M.; Volpi, L.; Pini, M.; Siligardi, C.; Settembre-Blundo, D. Identifying the Equilibrium Point between Sustainability Goals and Circular Economy Practices in an Industry 4.0 Manufacturing Context Using Eco-Design. Soc. Sci. 2019, 8, 241. [CrossRef]

96. Mishra, J.L.; Chiwenga, K.D.; Ali, K. Collaboration as an enabler for circular economy: A case study of a developing country. Manag. Decis. 2019. [CrossRef]

97. Romero-Hernández, O.; Romero, S. Maximizing the value of waste: From waste management to the circular economy. Thunderbird Int. Bus. Rev. 2018, 60, 757-764. [CrossRef]

98. Francisco de Oliveira, G.; Rabechini, R., Jr. Stakeholder management influence on trust in a project: A quantitative study. Int. J. Proj. Manag. 2019, 37, 131-144. [CrossRef]

99. Sun, D.; Hyland, P.; Cui, H. A Designed Framework for Delivering Systems Thinking Skills to Small Business Managers. Systems 2014, 2, 297-312. [CrossRef]

100. Bocken, N.; Rana, P.; Short, S. Value mapping for sustainable business thinking. J. Ind. Prod. Eng. 2015, 32, 67-81. [CrossRef]

101. Atwater, J.B.; Pittman, P.H. Facilitating Systemic Thinking in Business Classes. Decis. Sci. J. Innov. Educ. 2006, 4, 273-292. [CrossRef]

102. Bruni, R.; Carrubbo, L.; Cavacece, Y.; Sarno, D. An Overview of the Contribution of Systems Thinking Within Management and Marketing. In Social Dynamics in a Systems Perspective; Springer: Berlin/Heidelberg, Germany, 2018; pp. 241-259.

103. J-Figueiredo, R.; Quelhas, O.L.G.; Bahli, B. Sustainability and Innovation in the Value Chain: An Analysis of a Case Study. In Knowledge, Innovation and Sustainable Development in Organizations; Springer: Berlin/Heidelberg, Germany, 2019; pp. 231-249.

104. de Jesus, A.; Antunes, P.; Santos, R.; Mendonça, S. Eco-innovation pathways to a circular economy: Envisioning priorities through a Delphi approach. J. Clean. Prod. 2019, 228, 1494-1513. [CrossRef]

105. Hong, J.; Zheng, R.; Deng, H.; Zhou, Y. Green supply chain collaborative innovation, absorptive capacity and innovation performance: Evidence from China. J. Clean. Prod. 2019, 241. [CrossRef]

106. McGrath, R.; Tsai, M.; Venkataraman, S.; MacMillan, I. Innovation, Competitive Advantage and Rent: A Model and Test. Manag. Sci. 1996, 42, 389-403. [CrossRef]

107. Bennett, N.J.; Whitty, T.S.; Finkbeiner, E.; Pittman, J.; Bassett, H.; Gelcich, S.; Allison, E.H. Environmental Stewardship: A Conceptual Review and Analytical Framework. Environ. Manag. 2018, 61, 597-614. [CrossRef]

108. Senge, P.M. The Leader's New Work: Building Learning Organizations. Sloan Manag. Rev. 1990, 32, 1-39.

109. Guimaraes, T.; Sato, O. Benefits of Environmental Stewardship. J. Transnatl. Manag. Dev. 1997, 2, 59-80. [CrossRef]

110. ISO. ISO 44001:2017 Collaborative Business Relationship Management Systems-Requirements And Framework; ISO: Geneva, Switzerland, 2017; pp. 1-60.

111. Bjärstig, T. Does Collaboration Lead to Sustainability? A Study of Public-Private Partnerships in the Swedish Mountains. Sustainability 2017, 9, 1685. [CrossRef]

112. Senge, P.M. The Fifth Discipline: The Art \& Practice of The Learning Organization; Crown Publishing Group: New York, NY, USA, 2010; ISBN 0307477649.

113. Gao, Y.; Li, Z.; Taghipour, A.; Canel, B.; Kang, D.S. Supply Chain Coordination: A Review. J. Adv. Manag. Sci. 2018, 6, 213-217. [CrossRef]

114. Planko, J.; Chappin, M.M.H.; Cramer, J.; Hekkert, M.P. Coping with coopetition-Facing dilemmas in cooperation for sustainable development: The case of the Dutch smart grid industry. Bus. Strateg. Environ. 2019, 28, 665-674. [CrossRef]

115. De Freitas, D.C.; De Oliveira, L.G.; Alcantara, R.L.C. Collaborative initiatives: motivators, barriers and benefits. RAM. Rev. Adm. Mackenzie 2018, 19. [CrossRef]

116. Chou, S.; Chen, C.-W.; Kuo, Y.-T. Flexibility, collaboration and relationship quality in the logistics service industry. Asia Pac. J. Mark. Logist. 2018, 30, 555-570. [CrossRef]

117. Hanna, J.B.; Skipper, J.B.; Hall, D. Mitigating supply chain disruption: The importance of top management support to collaboration and flexibility. Int. J. Logist. Syst. Manag. 2010, 6, 397. [CrossRef]

118. Gumboh, J.; Gichira, R. Supply Chain Collaboration among SMEs in Kenya: A Review of Collaboration Barriers. Int. J. Humanit. Soc. Sci. 2015, 5, 223-229. 
119. Schulz, M. An Analysis of LEGO's Response to an Attack on its Partnership with Royal Dutch Shell. Elon J. Undergrad. Res. Commun. 2016, 7, 60-69.

120. Frandsen, S.; Kuhn, T.; Wolff Lundholt, M. Counter Narratives and Organization; Routledge: New York, NY, USA, 2016; ISBN 1317399498.

121. Polverini, D.; Miretti, U. Resources, Conservation \& Recycling An approach for the techno-economic assessment of circular economy requirements under the Ecodesign Directive. Resour. Conserv. Recycl. 2019, 150. [CrossRef]

122. Berggren, E.; Bernshteyn, R. Organizational transparency drives company performance. J. Manag. Dev. 2007, 26, 411-417. [CrossRef]

123. Fernandez-Feijoo, B.; Romero, S.; Ruiz, S. Effect of Stakeholders' Pressure on Transparency of Sustainability Reports within the GRI Framework. J. Bus. Ethics 2014, 122, 53-63. [CrossRef]

124. Duan, Z.; Guo, P.; Li, W.; Yu, M.; Zhang, H.; Zou, J.; Zorn, M. Road to Transparency: Relationship to Risks and How It Is Perceived and Handled by Chinese Extractive Companies Involved in Overseas Investment. J. Int. Bus. Ethics 2015, 8, 44-65.

125. Hassan Che Haat, M.; Abdul Rahman, R.; Mahenthiran, S. Corporate governance, transparency and performance of Malaysian companies. Manag. Audit. J. 2008, 23, 744-778. [CrossRef]

126. Thøger Christensen, L. Corporate communication: The challenge of transparency. Corp. Commun. An Int. J. 2002, 7, 162-168. [CrossRef]

127. Mullinix, K.J.; Leeper, T.J.; Druckman, J.N.; Freese, J. The Generalizability of Survey Experiments. J. Exp. Polit. Sci. 2015, 2, 109-138. [CrossRef]

128. Nazarko, J.; Ejdys, J.; Halicka, K.; Magruk, A.; Nazarko, Ł.; Skorek, A. Application of Enhanced SWOT Analysis in the Future-oriented Public Management of Technology. Procedia Eng. 2017, 182, 482-490. [CrossRef]

(C) 2020 by the authors. Licensee MDPI, Basel, Switzerland. This article is an open access article distributed under the terms and conditions of the Creative Commons Attribution (CC BY) license (http://creativecommons.org/licenses/by/4.0/). 